\title{
Sediment transport on the inner shelf off Khao Lak (Andaman Sea, Thailand) during the 2004 Indian Ocean tsunami and former storm events: evidence from foraminiferal transfer functions
}

\author{
Y. Milker ${ }^{1}$, M. Wilken ${ }^{1}$, J. Schumann ${ }^{1}$, D. Sakuna ${ }^{2}$, P. Feldens ${ }^{2,3}$, K. Schwarzer ${ }^{2}$, and G. Schmiedl ${ }^{1}$ \\ ${ }^{1}$ Center of Earth System Research and Sustainability, University of Hamburg, Hamburg, Germany \\ ${ }^{2}$ Institute of Geosciences, Coastal and Shelf Research, University of Kiel, Kiel, Germany \\ ${ }^{3}$ GEOMAR Helmholtz Centre for Ocean Research Kiel, Kiel, Germany \\ Correspondence to: Y. Milker (yvonne.milker@uni-hamburg.de)
}

Received: 29 March 2013 - Published in Nat. Hazards Earth Syst. Sci. Discuss.: 29 May 2013

Revised: 29 October 2013 - Accepted: 2 November 2013 - Published: 5 December 2013

\begin{abstract}
We have investigated the benthic foraminiferal fauna from sediment event layers associated with the 2004 Indian Ocean tsunami and former storms that have been retrieved in short sediment cores from offshore environments of the Andaman Sea, off Khao Lak, western Thailand. Species composition and test preservation of the benthic foraminiferal faunas exhibit pronounced changes across the studied sections and provide information on the depositional history of the tsunami layer, particularly on the source water depth of the displaced foraminiferal tests. In order to obtain accurate bathymetric information on sediment provenance, we have mapped the distribution of modern faunas in non-tsunamigenic surface sediments and created a calibration data set for the development of a transfer function. Our quantitative reconstructions revealed that the resuspension of sediment particles by the tsunami wave was restricted to a maximum water depth of approximately $20 \mathrm{~m}$. Similar values were obtained for former storm events, thus impeding an easy distinction of different high-energy events.
\end{abstract}

\section{Introduction}

The devastating tsunami of 26 December 2004 that originated from a 9.3 magnitude submarine earthquake off the northwest coast of the Indonesian island Sumatra (Stein and Okal, 2005) (Fig. 1) had severe impacts on the coastlines of southeastern Asia (Bell et al., 2005; Tsuji et al., 2006). The highly energetic tsunami wave resulted in major coastal changes and is documented in on- and offshore erosion phenomena and deposits. Detailed topographic, sedimentologi$\mathrm{cal}$ and geochemical investigations documented the complex nature of erosion and deposition processes of the tsunami wave and its backflow along the western coast of Thailand (Choowong et al., 2007; Fagherazzi and Du, 2007; Hawkes et al., 2007; Jankaew et al., 2008; Mard Karlsson et al., 2009; Feldens et al., 2009; Sakuna et al., 2012). However, little is known on the exact provenance and transport dynamics of sediment particles in tsunamigenic offshore deposits. Specific sedimentological characteristics such as thickness of the high-energy layer, its grain size distribution and sorting have been studied by several authors in order to distinguish between storm and tsunami events (e.g., Morton et al., 2007; Kortegaas and Dawson, 2007; Dahanayake and Kulasena, 2008). These studies also revealed that it is often difficult to separate a storm layer from a tsunami layer from the sedimentological record alone.

Among other microfossils, benthic foraminifers are frequently found in tsunami deposits, providing information on the provenance of the sediment components (review by Mamo et al., 2009). Size distribution, shape and preservation of foraminiferal tests document the hydrodynamics of the tsunami wave but are also influenced by rapid post-depositional taphonomic processes (Yawsangratt et al., 2011). The occurrence of certain marine taxa in onshore tsunamites allowed for an assessment of the water depth range from which sediment particles have been resuspended and incorporated into the tsunami wave (e.g., Nanayama and 


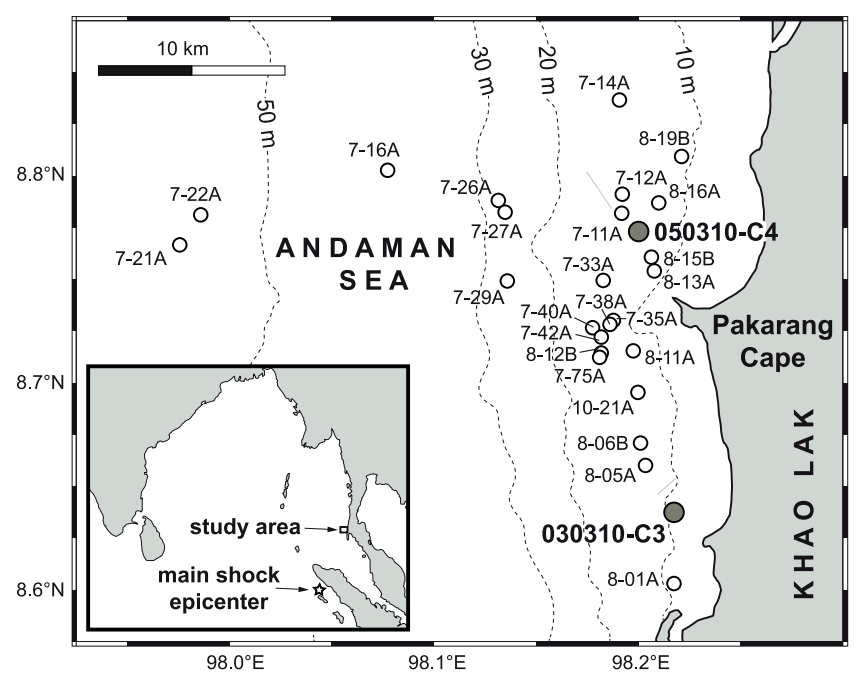

Fig. 1. Bathymetric map of the study area on the inner shelf of the eastern Andaman Sea off Cape Pakarang, Khao Lak, southwestern Thailand. Shown are the locations of the investigated surface sediment sites (small open circles) and the core sites (large grey circles) addressed in this study. See Table 1 for station details. The positions of the study area and the main shock of the 26 December 2004 earthquake are marked in the overview map of the northern Indian Ocean.

Shigeno, 2006; Uchida et al., 2010). Typically, the tsunamite assemblages contain open-shelf taxa, contrasting with lower diverse brackish faunas in under- and overlying marsh or other terrestrial sediments (Uchida et al., 2010). However, the published water depth estimates vary significantly, ranging from $30 \mathrm{~m}$ or shallower for a historical tsunami of southeastern India (Satyanarayana et al., 2007) up to $90 \mathrm{~m}$ for the 1992 tsunami of Hokkaido (Nanayama and Shigeno, 2006), and between 50 and $300 \mathrm{~m}$ for various tsunamites in Japan and southeastern Asia (Uchida et al., 2010). This compilation demonstrates that even tests from outer shelf to upper bathyal taxa have been documented in tsunamites (Dominey-Howes et al., 1998; Uchida et al., 2010). Sugawara et al. (2009) studied the foraminiferal content of offshore deposits of the southwest coast of Thailand related to the 2004 Indian Ocean tsunami on 4 stations from $4.5 \mathrm{~m}$ to $20.5 \mathrm{~m}$ water depth. The studied faunas reveal a significant backwash component but lack evidence for transport of particles from deeper to shallower water depth which might result from their sampling strategy. To date, all of these depth estimates have been based on qualitative information of bathymetric species ranges or hydrodynamic estimation of the tsunami wave and therefore remain relatively inaccurate.

In tropical and subtropical regions, the distribution of benthic shelf foraminifers depends on various factors, such as food availability and quality, substrate-type, bottom current velocity, temperature and salinity, vegetation and light penetration (e.g, Szarek et al., 2006; Murray, 2006; Parker and Gischler, 2011). The specific environmental setting is commonly reflected in a distinct depth zonation of shelf species. Of particular relevance are symbiont-bearing larger foraminifers that are adapted to limited depth intervals within the photic zone, depending on the specific light requirements of the algal symbiont and other habitat variables such as microscale environmental gradients within the substrate (Hohenegger et al., 1999; Beavington-Penney and Racey, 2004; Renema, 2006a, b). Different quantitative methods have been developed for water depth estimates, e.g, based on the ratio between benthic and planktonic foraminifers (Van der Zwaan et al., 1990), and the distribution patterns of certain faunas and benthic indicator taxa (Horton et al., 1999; Hohenegger, 2005; Milker et al., 2009). These methods have been successfully applied to paleobathymetric reconstructions in various sedimentary environments (e.g., Nelson et al., 2008; Rossi and Horton, 2009; Hawkes et al., 2010; Milker et al., 2011) and also bear a high potential for quantitative provenance studies of tsunami deposits.

The overall target of the present study is to generate quantitative data on the provenance of foraminiferal tests in highenergy event deposits from the inner shelf off Khao Lak, comprising layers of the 2004 tsunami and former storm events. For this, benthic foraminifers have been quantitatively analyzed from surface sediment samples and from two sediment cores retrieved from selected depositional systems of the inner shelf of the study area. The recent data set was used to establish a transfer function for water depth that was then applied to the fossil faunas. Our data will be particularly useful for sedimentological and modeling studies on hydrodynamics, wavelength and amplitude of tsunami waves. They will also contribute to the toolbox for distinguishing between storm and tsunami deposits.

\section{Study area}

The study area is situated $25 \mathrm{~km}$ off the Khao Lak region (Thailand) near Pakarang Cape (Andaman Sea) and covers an area of $\sim 1000 \mathrm{~km}^{2}$ (Table 1, Fig. 1). The Andaman Sea is a marginal sea, separated from the Indian Ocean by the Nicobar and Andaman Islands. It is characterized by a relatively broad shelf region up to $200 \mathrm{~km}$ wide in the north, and a narrower shelf region in the south (Saidova, 2008). The absence of major riverine influence results in sedimentation of mixed siliciclastic-carbonate sediments, in many places dominated by coral-algal sand (Saidova, 2008; Feldens et al., 2009). The region is influenced by the monsoonal system with northeasterly winds during winter and southwesterly winds during summer. The monsoon system also accounts for the hydrologic properties of surface water masses. The summer monsoon results in stronger waves, influencing the coastal dynamics (Scheffers et al., 2012). In the southern Andaman Sea, the yearly range of surface water temperatures is $26-29^{\circ} \mathrm{C}$; surface salinities range between 31.5 and 33 psu (Levitus and Boyer, 1994; Varkey et al., 1996). The 
Table 1. Surface sample and sediment core IDs, sampling year, longitude and latitude, and water depth of the investigated surface samples and sediment cores (see also Fig. 1).

\begin{tabular}{|c|c|c|c|c|c|c|}
\hline $\begin{array}{l}\text { Sample/core } \\
\text { ID }\end{array}$ & $\begin{array}{r}\text { Sampling } \\
\text { period }\end{array}$ & $\begin{array}{l}\text { Code in this } \\
\text { study (RDA) }\end{array}$ & $\begin{array}{l}\text { Type of } \\
\text { material }\end{array}$ & Longitude & Latitude & $\begin{array}{r}\text { Water depth } \\
(\mathrm{m})\end{array}$ \\
\hline $021207-11 \mathrm{~A}$ & $12 / 2007$ & 1 & surface sample & $08^{\circ} 46.901$ & $98^{\circ} 11.512$ & 20.1 \\
\hline $021207-12 \mathrm{~A}$ & $12 / 2007$ & 2 & surface sample & $08^{\circ} 47.459$ & $98^{\circ} 11.528$ & 20.1 \\
\hline 021207-14A & $12 / 2007$ & 3 & surface sample & $08^{\circ} 50.189$ & $98^{\circ} 11.433$ & 18.7 \\
\hline 021207-16A & $12 / 2007$ & 4 & surface sample & $08^{\circ} 48.147$ & $98^{\circ} 04.652$ & 44.7 \\
\hline 031207-21A & $12 / 2007$ & 5 & surface sample & $08^{\circ} 45.989$ & $97^{\circ} 58.549$ & 63.4 \\
\hline 031207-22A & $12 / 2007$ & 6 & surface sample & $08^{\circ} 46.860$ & $97^{\circ} 59.166$ & 61.8 \\
\hline 031207-26A & $12 / 2007$ & 7 & surface sample & $08^{\circ} 47.278$ & $98^{\circ} 07.884$ & 33.6 \\
\hline 031207-27A & $12 / 2007$ & 8 & surface sample & $08^{\circ} 46.932$ & $98^{\circ} 08.094$ & 26.5 \\
\hline 031207-29A & $12 / 2007$ & 9 & surface sample & $08^{\circ} 44.938$ & $98^{\circ} 08.154$ & 25.1 \\
\hline 051207-33A & $12 / 2007$ & 10 & surface sample & $08^{\circ} 44.958$ & $98^{\circ} 10.965$ & 17.0 \\
\hline 051207-35A & $12 / 2007$ & 11 & surface sample & $08^{\circ} 43.796$ & $98^{\circ} 11.270$ & 15.2 \\
\hline 051207-38A & $12 / 2007$ & 12 & surface sample & $08^{\circ} 43.682$ & $98^{\circ} 11.168$ & 15.1 \\
\hline $051207-40 \mathrm{~A}$ & $12 / 2007$ & 13 & surface sample & $08^{\circ} 43.584$ & $98^{\circ} 10.655$ & 17.8 \\
\hline $051207-42 \mathrm{~A}$ & $12 / 2007$ & 14 & surface sample & $08^{\circ} 43.319$ & $98^{\circ} 10.908$ & 15.7 \\
\hline 081207-75A & $12 / 2007$ & 15 & surface sample & $08^{\circ} 42.744$ & $98^{\circ} 10.866$ & 16.5 \\
\hline 061208-01A & $12 / 2008$ & 16 & surface sample & $08^{\circ} 36.181$ & $98^{\circ} 13.044$ & 10.3 \\
\hline 061208-05A & $12 / 2008$ & 17 & surface sample & $08^{\circ} 39.600$ & $98^{\circ} 12.217$ & 13.0 \\
\hline 061208-06II-B2 & $12 / 2008$ & 18 & surface sample & $08^{\circ} 40.250$ & $98^{\circ} 12.067$ & 13.3 \\
\hline $061208-11 \mathrm{~A}$ & $12 / 2008$ & 19 & surface sample & $08^{\circ} 42.917$ & $98^{\circ} 11.850$ & 14.9 \\
\hline 061208-12B & $12 / 2008$ & 20 & surface sample & $08^{\circ} 42.860$ & $98^{\circ} 10.922$ & 19.4 \\
\hline 061208-13A & $12 / 2008$ & 21 & surface sample & $08^{\circ} 45.233$ & $98^{\circ} 12.460$ & 12.6 \\
\hline 061208-15B & $12 / 2008$ & 22 & surface sample & $08^{\circ} 45.639$ & $98^{\circ} 12.372$ & 14.0 \\
\hline 061208-16A & $12 / 2008$ & 23 & surface sample & $08^{\circ} 47.200$ & $98^{\circ} 12.592$ & 15.4 \\
\hline 061208-19B & $12 / 2008$ & 24 & surface sample & $08^{\circ} 48.548$ & $98^{\circ} 13.265$ & 13.0 \\
\hline $030310-21 \mathrm{~A}$ & $03 / 2010$ & 25 & surface sample & $08^{\circ} 41.720$ & $98^{\circ} 11.982$ & 15.2 \\
\hline 030310-C3 & $03 / 2010$ & & sediment core & $08^{\circ} 38.708$ & $98^{\circ} 12.931$ & 9.5 \\
\hline 050310-C4 & $03 / 2010$ & & sediment core & $08^{\circ} 46.659$ & $98^{\circ} 12.269$ & 15.3 \\
\hline
\end{tabular}

Andaman Sea is influenced by micro- to mesotidal semidiurnal tides with a tidal range from 1.1 to $3.6 \mathrm{~m}$ (Thampanya et al., 2006). This coastal region of the Andaman Sea is relatively unaffected by strong tropical cyclones. Typhoons can occur in the study area but their frequency is low (Kumar et al., 2008; Phantuwongraj and Choowong, 2012). The absence of larger riverine discharge (Feldens et al., 2009) as well as the absence of large storm events between the deposition of the 2004 tsunami deposits and the sampling campaigns from 2007 to 2010 (Regional Specialized Meteorological Centre (RMSC), New Delhi) allows for the investigation of depositional processes prior to, during and after the tsunami event in 2004.

\section{Material and methods}

\subsection{Surface sediment samples and sediment cores}

For this study, a total of 25 surface samples and two sediment cores, taken from the investigation area during three research cruises (November-December 2007, NovemberDecember 2008, February-March 2010), were investigated (Fig. 1, Table 1). The surface samples were collected with a grab sampler from water depth ranging from 10.3 to $63.4 \mathrm{~m}$. The sites were selected based on detailed sea-floor mapping (Feldens et al., 2009, 2012) with high-resolution hydroacoustic systems (side-scan sonar, shallow seismic systems, multibeam echosounder) and an underwater video camera in order to cover a maximum variety of substrates and to get a clear picture of sediment distribution patterns and morphological features. The two sediment cores were recovered with a Rumohr gravity corer at $9.5 \mathrm{~m}$ water depth (core 030310C3, length $97 \mathrm{~cm}$ ) and $15.3 \mathrm{~m}$ water depth (core 050310-C4, length $56 \mathrm{~cm}$ ) (Fig. 1; Table 1).

According to different lithological units of the cores, nine samples of $1 \mathrm{~cm}$ thickness were investigated from core 030310-C3 and eight samples from core 050310-C4 (for sampling position see Fig. 2). Six samples of core 030310C3 and four samples of core 050310-C4 were taken from layers characterized by coarser-grained units. Three samples from core 030310-C3 and four samples from core 050310-C4 were taken from finer-grained layers deposited under normal background sedimentation. Two surface samples were taken onshore to investigate specimens redeposited during the 2004 tsunami. 


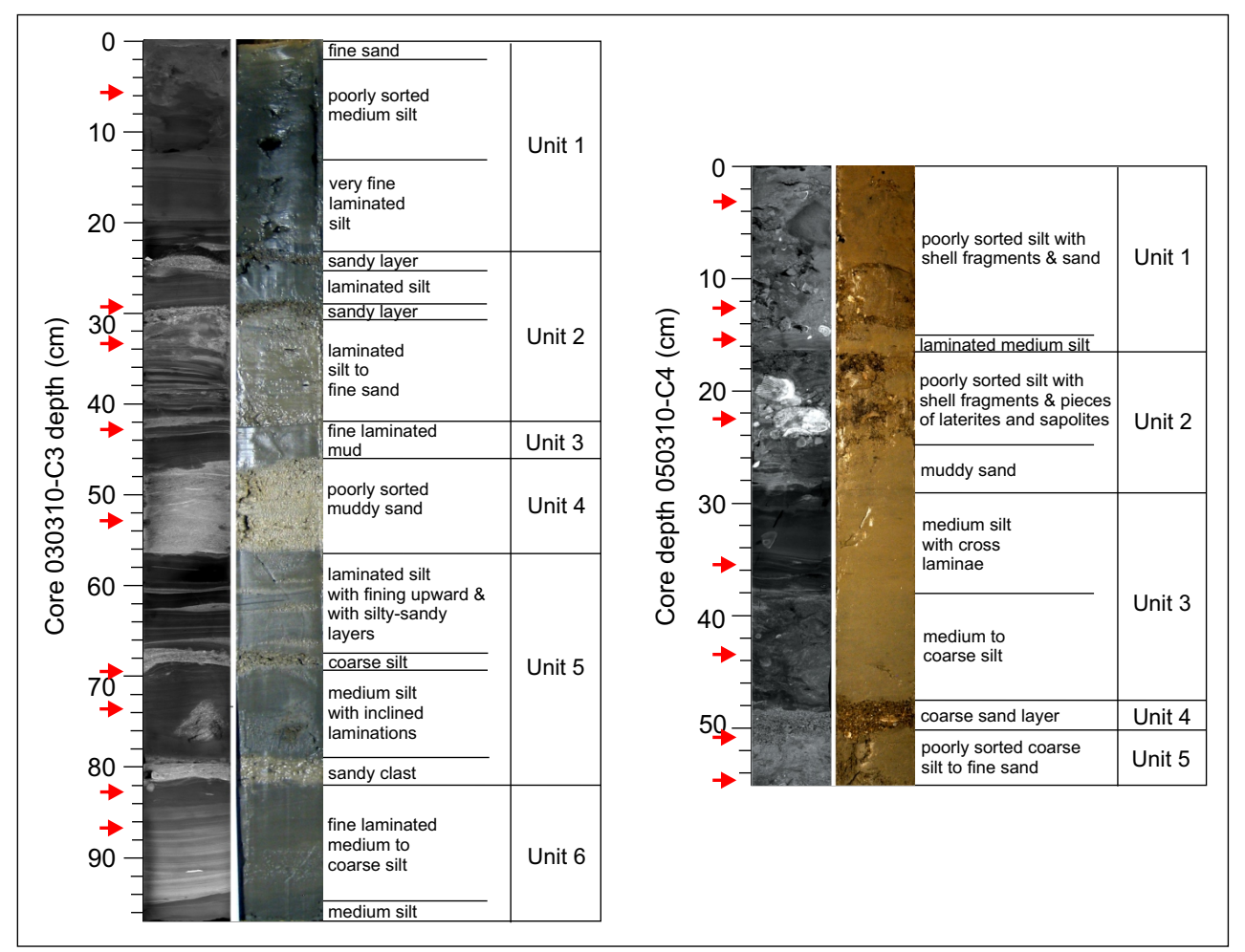

Fig. 2. Photographs, X-radiographs and definition of lithological units of sediment cores 030310-C3 and 050310-C4 versus core depth. The red arrows mark sample positions investigated in the frame of this study.

\subsection{Foraminiferal and environmental data}

Both the surface and core samples were wet-sieved with a $63 \mu \mathrm{m}$ sieve. The fraction $>63 \mu \mathrm{m}$ was dried at $40{ }^{\circ} \mathrm{C}$ for later foraminiferal analysis. The modern and fossil faunas were investigated from the $>125 \mu \mathrm{m}$ fraction using representative splits containing approximately 300 benthic foraminiferal specimens. The identification of the foraminifera on the species level was mainly based on the studies of Hottinger et al. (1993), Jones (1994) and Hohenegger et al. (1999). Rare species or specimens that could not be identified on the species level were grouped into their genus or family. Potentially relocated benthic foraminifera (broken tests, tests fragments, and tests with yellowish-brown coloration) were counted separately.

In order to extract the dominant modern and fossil benthic foraminiferal assemblages, a principal component analysis (PCA) in Q-mode and with varimax rotation was carried out on the surface samples. A total of 53 modern foraminiferal taxa having relative minimum abundances of $0.5 \%$ on the total fauna and being present in at least 3 samples were included into analysis. All potentially relocated specimens were excluded. The number of principal components (PCs) was selected based on eigenvalues $>1$. PC loadings $\geq 0.4$ for each axis were defined as significant (Malmgren and Haq, 1982; Backhaus et al., 2006).
In order to examine the relationship between the modern species in the data set of the surface samples and environmental parameters, a redundancy analysis (RDA) was carried out using Canoco (version 4.5) (Ter Braak and Smilauer, 2002; Leps and Smilauer, 2003). We selected the water depth and the percentages of silt and clay $(<63 \mu \mathrm{m})$, fine sand $(63-125 \mu \mathrm{m})$ and coarser-grained sediment $(>125 \mu \mathrm{m})$ as environmental parameters. We used a reduced surface data set with 23 species having percentages exceeding $5 \%$ in the total assemblage. Species counts were square-roottransformed and environmental parameters were standardized before analysis. Partial RDAs (with each environmental variable as the only variable) were calculated to evaluate the individual influence of the environmental parameters on the foraminiferal assemblages.

\subsection{Development of foraminiferal-based transfer functions}

We applied the detrended canonical correspondence analysis (DCCA) on the same reduced modern data set used for RDA (containing 23 species with percentages higher than $5 \%$ ) on the total fauna to analyze whether the species show a linear or unimodal distribution in relation to water depth (Birks, 1998, 1995). Birks (1995) suggests the use of linear regression methods for DCCA gradient lengths below 2 SD 
standard deviation (SD) units, and unimodal methods for gradient lengths larger than 2 SD units. For this approach, we used the CANOCO software package (version 4.5) (Leps and Smilauer, 2003; Ter Braak and Smilauer, 2002).

For the development of the transfer function, the modern (training) data set was reduced to benthic foraminifera, identified on the species level, and with relative abundances of $>0.5 \%$ on the total dead assemblages. The fossil data sets were reduced to benthic species present in the surface data set. Potentially relocated specimens were removed from the training data set. The final modern data set consisted of 25 surface samples with a total of 49 dead species, ranging from 10.3 to $63.4 \mathrm{~m}$ water depth. In the fossil data sets, a total of 37 species from core $030310-\mathrm{C} 3$ and 38 species from core 050310-C4 were used for reconstruction.

The modern analog technique (MAT) was applied to test whether the fossil samples provide good analogs for the modern samples by calculating dissimilarity coefficients (MinDC (minimum distance to closest analog) dissimilarity coefficients) (Birks, 1995). We selected the square chord distance as the dissimilarity coefficient (Overpeck et al., 1985) and the seven most similar modern samples. Coefficients lower than the 10th percentile have been defined as good analogs, coefficients between the 10th and 20th percentile have been considered as fair analogs and coefficients larger than the 20th percentile as poor analogs (Horton and Edwards, 2006; Birks, 1995; Kemp et al., 2009). For all calculations we used the $\mathrm{C}^{2}$ software package (version 1.7.2) (Juggins, 2003).

We tested three methods for the paleo-water depth estimates in the sediment cores: the partial least squares (PLS) method that is based on a linear species-environment relationship, the weighted averaging (WA) that is based on a unimodal species-environment relationship and finally the combination of both methods, the WA-PLS method. The latter is presented here. The WA-PLS method creates new components from a data set by maximizing the covariance between the scores of the independent variable (water depth) and the dependent variables (species abundances) (Birks, 1998; Ter Braak and Juggins, 1993).

In order to obtain a normal distribution, species counts were square-root-transformed. In order to evaluate the performance of the transfer functions, we used the apparent coefficient of determination $\left(R^{2}\right)$, allowing for an evaluation of the strength of the linear relationship between the observed and estimated water depths in the surface data set. In order to calculate the coefficient of determination of prediction $\left(R_{\text {jack }}^{2}\right)$ and the root mean squared error of prediction (RMSEP) in the surface data set, we used the "jack-knifing" (leave one out) cross-validation technique (Horton and Edwards, 2006; Ter Braak and Juggins, 1993). Bootstrapping cross-validation (1000 cycles) was selected to evaluate the sample-specific errors of prediction in the fossil data sets (Birks et al., 1990; Horton and Edwards, 2006). The number of components for WA-PLS was selected according to the lowest RMSEP values if the reduction in prediction error exceeds $5 \%$ for this component compared to the next lower component (Ter Braak and Juggins, 1993). All calculations were performed with the $\mathrm{C}^{2}$ software, version 1.7.2 (Juggins, 2003).

\section{Results}

\subsection{Lithology and sediment characteristics of sediment cores}

The surface sediments are composed of a mixture of siliciclastic and carbonate particles of varying proportions and grain sizes. The biogenic components predominantly comprise coral and algal fragments, mollusc shells, echinoid fragments and benthic foraminifers. Differences are also characterized by the sand content $(>63 \mu \mathrm{m})$ ranging from approximately 6 and to almost $100 \%$ (Table S1). Most samples exhibit high sand contents exceeding $90 \%$. Local exceptions are restricted to several shallow mud-dominated sites (6-32\% sand) and the deepest sites (67-68\% sand).

The sediment cores were subdivided into different lithological units based on grain-size distributions and sedimentary structures, identified by visual inspection and/or by Xradiography images of the cores (Fig. 2).

Core 030310-C3 has been subdivided into six units (Fig. 2). Unit 6 consists of medium to coarse silt, with wellsorted medium silt in its lower part and finely laminated medium to coarse silt in its upper part. The contact to unit 5 is sharp and erosional. Unit 5 is mainly composed of very fine sand and silt. At its base a sandy clast, two $\mathrm{cm}$ in diameter, was found. The lower part of unit 5 consists of coarse silt followed by a subunit with medium silt showing some laminations, and a subunit of coarse silt. The upper part of unit 5 consists of laminated silt, showing a fining upward, and contains some mm-thick layers of coarse silt to very fine sand. Unit 4 is composed of a poorly sorted muddy sand layer and unit 3 consists of finely laminated mud. Unit 2 is composed of laminated clayey silt and contains two sand layers with laterites and shell fragments. The lower part of unit 2 consists of laminated silt to fine sand and the upper part is composed of slightly inclined laminated silt. The uppermost unit 1 consists of poorly sorted silt with a finely laminated silt subunit in the lower part and a medium silt subunit in the upper part.

Sediment core 050310-C4 has been subdivided into five units (Fig. 2). Unit 5 is composed of very poorly sorted coarse silt to fine sand and contains some shells. Unit 4 consists of a layer of coarse sand containing shell fragments. Unit 3 is composed of poorly sorted silt with medium-coarse silt in the lower part and medium silt in the upper part. The lower part of unit 2 is composed of muddy sand, while the upper part is an admixture of poorly to very poorly sorted silt, sand, gravels and shell fragments, clasts of sapolite, quartz and laterites. Unit 1, in the uppermost part of the core, consists of a laminated medium silt layer in the lowermost part followed by a subunit consisting of an admixture of poorly to very poorly sorted silt, sand, and shell fragments. 


\subsection{Distribution of foraminifera in the surface sediments}

In the surface sediments, we identified a total of 59 different species. The shallow sites contain a significant amount of larger foraminifera with higher percentages of Amphistegina radiata, Pararotalia stellata, Dentritina ambigua, Operculina ammonoides, Operculina complanata, Amphistegina lessonii, Amphistegina sp. 1 and Neorotalia calcar (Fig. 3, Appendix A). Further dominant taxa include Siphonaperta sp. 2 (with a maximum of $32.1 \%$ ), Quinqueloculina sp. 1 (14.7\%), Discorbinella bertheloti (19.3\%), Neoeponides praecinctus (16.8\%),Saidovina subangularis (14.1\%), Cibicidoides pseudoungerianus (17.2\%) and Quinqueloculina seminula $(9.1 \%)$. Most of these taxa show a distinct bathymetric zonation, with species occurring with higher numbers at the shallower stations such as P. stellata, Borelis schlumbergeri, A. lessonii, S. elliptica, D. ambigua and N. calcar; at stations with intermediate water depths such as $A$. radiata, $O$. ammonoides and $N$. praecinctus; and at stations with higher water depths such as S. subangularis and C. pseudoungerianus (Fig. 3).

We observed relatively high amounts of potentially redeposited specimens with maximum percentages of $24 \%$ (mean of $10.5 \%$ ) on the total assemblages at the shallower sites from approximately 10 to $30 \mathrm{~m}$ water depth, while the deeper sites contained lower amounts (mean of $3 \%$ ).

The PCA explains $89.1 \%$ of the total variance in the surface data set for the first six principal components (PCs) (Table 2). The stations deeper than $\sim 45 \mathrm{~m}$ water depth are dominated by a Neoeponides praecinctus-Operculina complanata assemblage (PC2) with S. subangularis, C. pseudoungerianus and D. bertheloti as associated species (Fig. 4, Table 2). This assemblage explains $10 \%$ of the total variance. The stations at intermediate water depths (between 16 and $34 \mathrm{~m}$ ) are characterized by the Amphistegina radiata assemblage, containing $O$. ammonoides and $N$. praecinctus as associated taxa (PC1) (Fig. 4, Table 2). This PC explains $14.3 \%$ of the total variance. The shallower stations, between 13 and $26 \mathrm{~m}$ water depth in the northern and middle part of the study area, are dominated by the Siphonaperta sp. 2 assemblage (PC3), with A. radiata, Quinqueloculina sp. 1 and $O$. ammonoides as associated species (Fig. 4, Table 2). This PC explains $38.5 \%$ of the total variance. The shallowest stations in the study area, with water depths between 10 and $15 \mathrm{~m}$, are characterized by three assemblages, each of them explaining almost $9 \%$ of the total variance in the data set (Fig. 4, Table 2). The Discorbinella bertheloti assemblage (PC4) appears in the southern part of the study area and includes Rosalina spp., Q. seminula, T. oblonga and A. tepida as associated taxa. The Operculina ammonoides-Dentritina ambigua assemblage (PC5) occurs in the northern part of the study area and contains A. lessonii as the most important associated species. Finally, the Pararotalia stellata assemblage (PC6) occurs in the southernmost part of the study area (Fig. 4).
Table 2. Results of the principal component analysis (see also Fig. 4) with the total variance explained by each principal component (PC) and the scores of the most important species. The species in bold, having the highest scores, are eponymous for the assemblages extracted from the surface samples.

\begin{tabular}{|c|c|c|c|}
\hline $\begin{array}{l}\mathrm{PC} \\
\text { axis }\end{array}$ & $\begin{array}{r}\text { Explained } \\
\text { variance }(\%)\end{array}$ & Species & Scores \\
\hline \multirow[t]{7}{*}{1} & \multirow[t]{7}{*}{14.29} & Amphistegina radiata & 5.71 \\
\hline & & Operculina ammonoides & 1.31 \\
\hline & & Neoeponides praecinctus & 1.24 \\
\hline & & Discorbinella bertheloti & 0.89 \\
\hline & & Amphistegina sp. & 0.74 \\
\hline & & Amphistegina lessonii & 0.62 \\
\hline & & Siphonaperta sp. 1 & 0.57 \\
\hline \multirow[t]{9}{*}{2} & \multirow[t]{9}{*}{10.08} & Neoeponides praecinctus & 3.32 \\
\hline & & Operculina complanata & 3.03 \\
\hline & & Saidovina subangularis & 2.85 \\
\hline & & Cibicidoides pseudoungerianus & 2.78 \\
\hline & & Discorbinella bertheloti & 2.26 \\
\hline & & Anomalinoides colligerus & 0.89 \\
\hline & & Reussella spinulosa & 0.70 \\
\hline & & Bolivina sp. & 0.56 \\
\hline & & Siphonaperta sp. 2 & 0.54 \\
\hline \multirow[t]{4}{*}{3} & \multirow[t]{4}{*}{38.50} & Siphonaperta sp. 2 & 5.80 \\
\hline & & Amphistegina radiata & 2.80 \\
\hline & & Quinqueloculina sp. 1 & 1.84 \\
\hline & & Operculina ammonoides & 1.11 \\
\hline \multirow[t]{5}{*}{4} & \multirow[t]{5}{*}{8.86} & Discorbinella bertheloti & 4.28 \\
\hline & & Rosalina spp. & 3.88 \\
\hline & & Quinqueloculina seminula & 1.96 \\
\hline & & Triloculina oblonga & 1.65 \\
\hline & & Ammonia tepida & 1.05 \\
\hline \multirow[t]{8}{*}{5} & \multirow[t]{8}{*}{8.86} & Operculina ammonoides & 3.49 \\
\hline & & Dentritina ambigua & 3.24 \\
\hline & & Amphistegina lessonii & 3.20 \\
\hline & & Siphonaperta sp. 3 & 1.38 \\
\hline & & Amphistegina sp. & 1.24 \\
\hline & & Borelis schlumbergeri & 1.23 \\
\hline & & Discorbinella bertheloti & 1.02 \\
\hline & & Pararotalia stellata & 1.02 \\
\hline \multirow[t]{6}{*}{6} & \multirow[t]{6}{*}{8.56} & Pararotalia stellata & 6.13 \\
\hline & & Amphistegina radiata & 1.89 \\
\hline & & Borelis schlumbergeri & 1.31 \\
\hline & & Quinqueloculina sp. 1 & 0.95 \\
\hline & & Elphidium craticulatum & 0.65 \\
\hline & & Quinqueloculina seminula & 0.61 \\
\hline
\end{tabular}

Associated species of this assemblage are A. radiata and $B$. schlumbergeri.

The results of the redundancy analysis (RDA) applied on the surface samples show that the water depth, explaining a total of $22 \%$ of the variance $(p>0.001)$ in the data set, is the most important environmental parameter, followed by the proportion of silt and clay (pelite) $(20.5 \%, p<0.002)$, fine sand $(19.5 \%, p<0.002)$ and the coarser fraction $(17.0 \%$, 


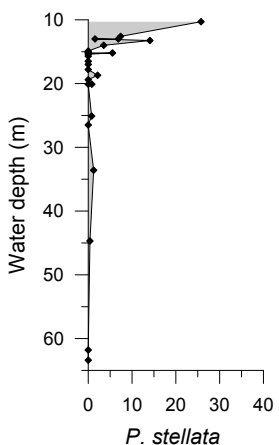

(\%)

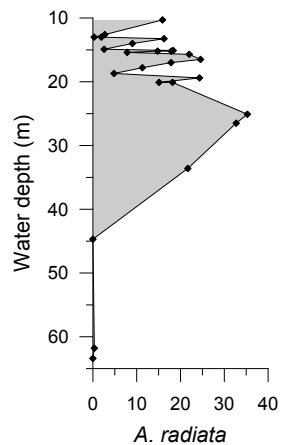

(\%)

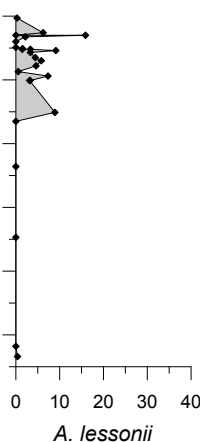

$(\%)$

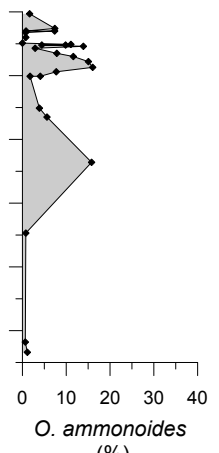

(\%)

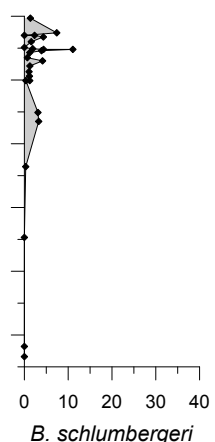

(\%)

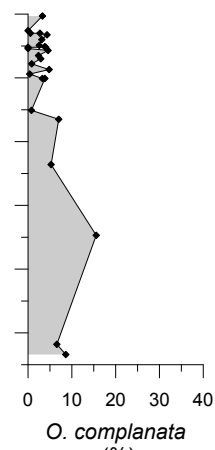

(\%)

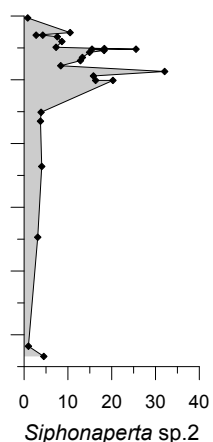

(\%)

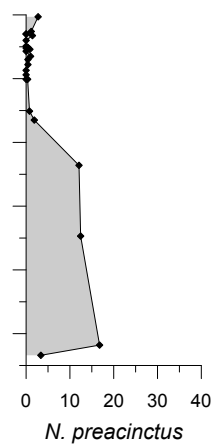

(\%)

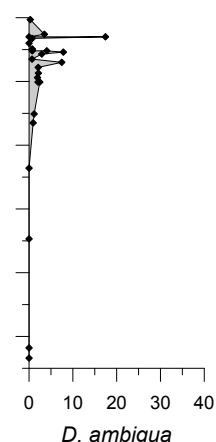

(\%)

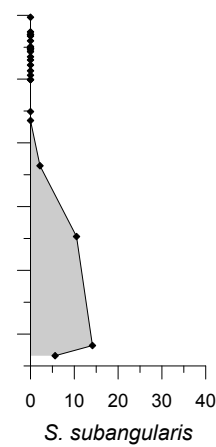

(\%)

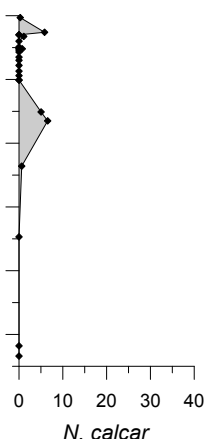

$(\%)$

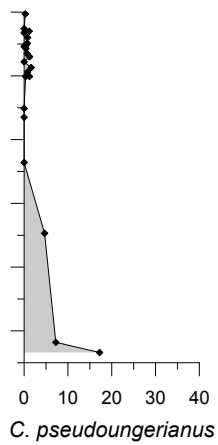

(\%)

Fig. 3. Relative abundance of selected recent benthic foraminifera from surface sediments versus water depth, showing a distinct bathymetric zonation. Only species having a relative abundance of $>5 \%$ on the recent assemblages are presented.

Table 3. Results of the redundancy analysis (RDA).

\begin{tabular}{|c|c|c|c|c|c|c|}
\hline Axes & 1 & 2 & 3 & 4 & $\begin{array}{r}\text { Captured } \\
\text { variance }(\%)\end{array}$ & $p$ value \\
\hline Eigenvalues & 0.296 & 0.135 & 0.068 & 0.014 & & \\
\hline Species-environment correlations & 0.905 & 0.945 & 0.802 & 0.529 & & \\
\hline $\begin{array}{l}\text { Cumulative percentage variance } \\
\text { of species data }\end{array}$ & 29.60 & 43.10 & 49.80 & 51.20 & & \\
\hline of species-environment relation & 57.80 & 84.10 & 97.30 & 100.00 & & \\
\hline \multicolumn{7}{|l|}{ Correlation } \\
\hline Water depth & 0.685 & -0.567 & 0.210 & -0.001 & 22.2 & $<0.001$ \\
\hline Fraction $<63$ mum & 0.699 & 0.245 & -0.426 & -0.123 & 20.5 & $<0.002$ \\
\hline Fraction $>125$ mum & -0.627 & -0.394 & 0.038 & 0.310 & 17.0 & $<0.001$ \\
\hline Fraction 63-125 mum & 0.643 & 0.438 & 0.398 & 0.098 & 19.5 & $<0.002$ \\
\hline
\end{tabular}

$p<0.001$ ) (Table 3). Water depth, pelite and fine sand are positively correlated to the first RDA axis, while the content of coarser-grained sediment is negatively correlated to the first RDA axis (Fig. 5, Table 3). This axis explains a total of $29.6 \%$ of the total variance in the data set (Table 3). Species of the PC2 assemblage, such as S. subangularis, C. pseudoungerianus, Anomalinoides colligerus, $N$. praecinctus, and $O$. complanata, show a clear correlation with increasing water depths, while other species, such as B. schlumbergeri and N. calcar, exhibit an association with lower water depths (Figs. 4 and 5). The species of the PC4 assemblage, such as D. bertheloti, T. oblonga, $Q$. seminula and A. tepida, show a correlation to finer-grained substrate. In contrast, $O$. ammonoides, Siphonaperta sp. 1 and Siphonaperta sp. 2 show a close relation to coarsergrained material. The species of the PC5 assemblage ( $A$. lessonii, D. ambigua and Siphonaperta sp. 3) together with A. radiata and Quinqueloculina sp. 1 exhibit a relation both to shallow water and to coarser-grained material (Figs. 4 and 5). 

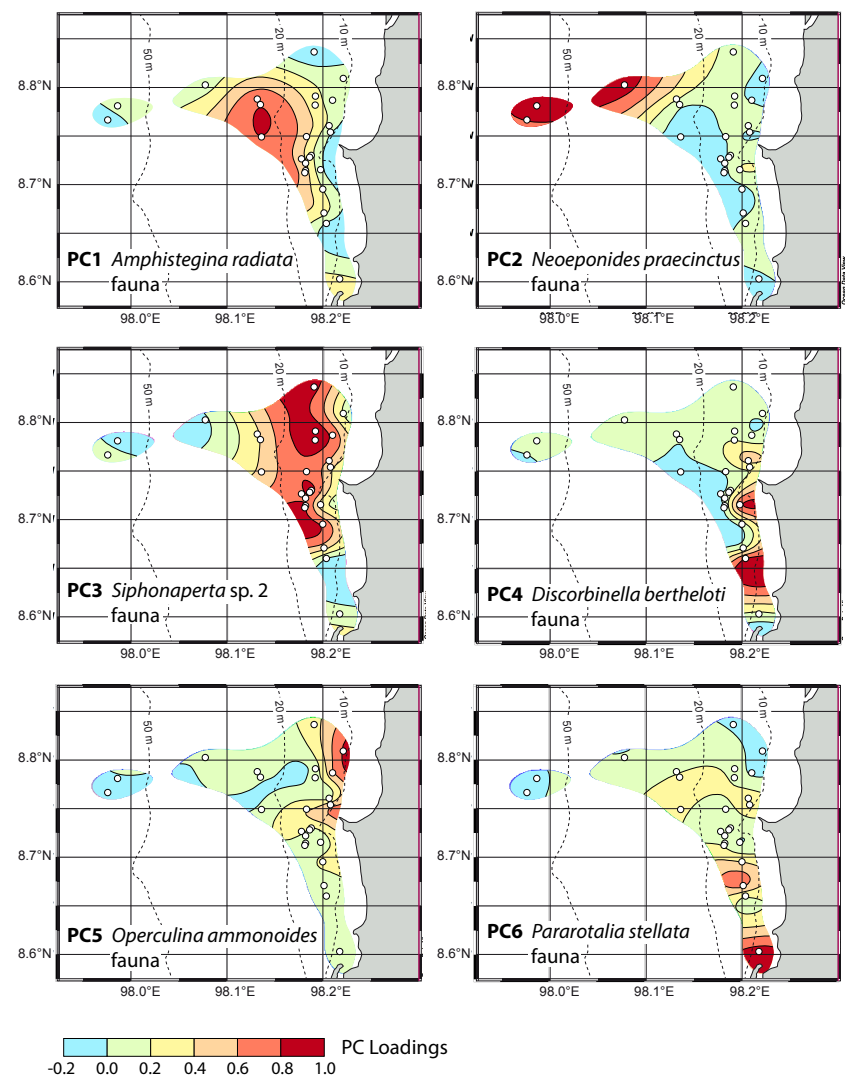

Fig. 4. Distribution of recent benthic foraminiferal assemblages extracted with Q-mode principal component analysis. Shown are PC loadings. Loadings $>0.4$ indicate statistically significant influence of the respective fauna (Malmgren and Haq, 1984). Ocean Data View (Schlitzer, 2012) was used for data interpolation. For scale bar see Fig. 1.

\subsection{Distribution of fossil foraminifera in the sediment cores}

Sediment core 030310-C3 contains a total of 48 fossil species, each with percentages larger than $1 \%$ on the total assemblages. The most abundant species in this core are $\mathrm{Am}$ phistegina radiata (with a maximum relative abundance of $21.4 \%)$, Siphonaperta sp. 2 (19.4\%), Discorbinella bertheloti (17.8\%) and Parrellina hispidula (11.9\%) (Fig. 6a, Appendix A). In addition, species with percentages between 5 and $10 \%$ include (in descending order) Quinqueloculina sp. 1, Elphidium craticulatum, Quinqueloculina seminula and Borelis schlumbergeri (Fig. 6a). Core 030310-C3 contains a very high content of redeposited tests with a mean value of $76 \%$. A maximum with $95 \%$ redeposited specimens was found in the lowermost part of the core at $86.5 \mathrm{~cm}$, and minimum values with $43-48 \%$ redeposited specimens were observed in the upper part of the core at 5.5 and $33.5 \mathrm{~cm}$ (Fig. 8).

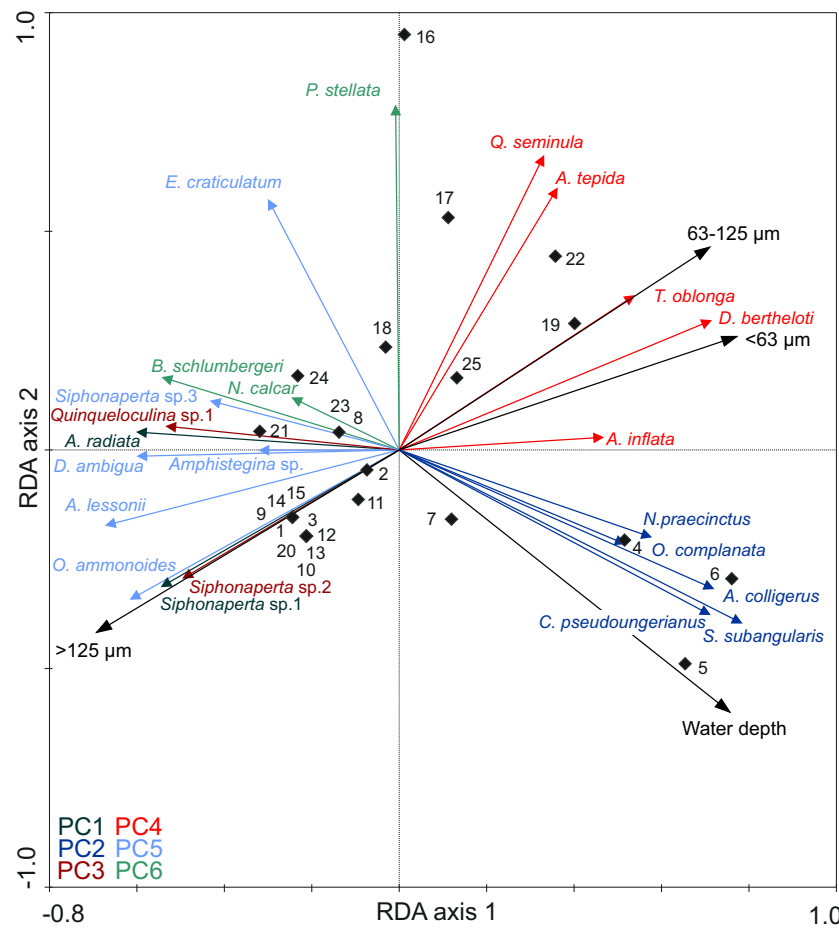

Fig. 5. Results of the redundancy analysis (RDA) applied on the surface samples (see also Table 3 ). The species arrows are colorized according to their membership to the principal components (PC) extracted from PCA (compare with Fig. 4). The distribution of recent foraminifers exhibits a strong relation to water depth but also to the grain size of the substrate. Species of the PC2 assemblage have a relation to deeper water depths and species of the PC6 assemblages occur more frequently at shallower water depths. For surface sample codes see Table 1 .

Sediment core $050310-\mathrm{C} 4$ contains a total of 33 fossil species, each with percentages larger than $1 \%$ on the total assemblages. The most dominant species in this core are $D$. bertheloti (with a maximum relative abundance of $21.2 \%$ ) and Siphonaperta sp. 2 (13.2\%) (Fig. 6b, Appendix A). Further species with relative abundances between 5 and $10 \%$ are (in descending order) Amphistegina sp. 1, A. radiata, Quinqueloculina sp. 1, Quinqueloculina seminula, Spiroloculina communis and Elphidium craticulatum (Fig. 6b). The content of potentially relocated specimens in core $050310-\mathrm{C} 4$ is lower than that observed in core 030310-C3, with a mean value of $48 \%$ (Fig. 8).

\subsection{Quantitative paleo-water depth reconstructions}

The short gradient length of 1.74 SD for the first axis of the DCCA implies a more linear distribution of the species in relation to water depth (Table 4). This can be explained by the limited water depth range (approximately 10 to $63 \mathrm{~m}$ ) included in this study, masking the common unimodal bathymetric species distributions. Although the weighted 
A: Sediment core 030310-C3

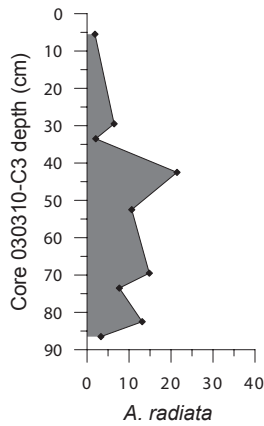

(\%)

B: Sediment core 050310-C4

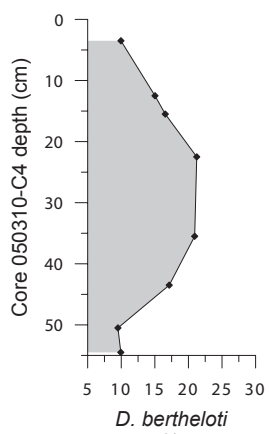

(\%)

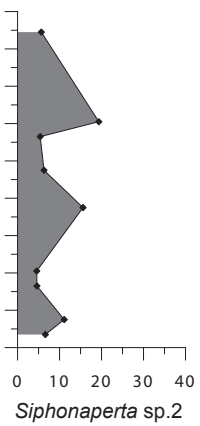

(\%)

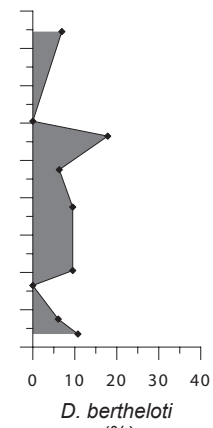

$(\%)$

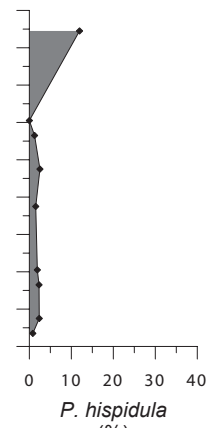

(\%)

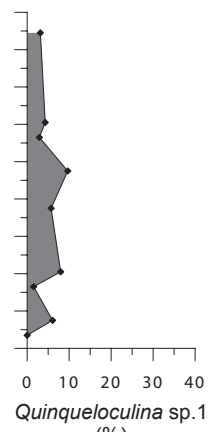

(\%)

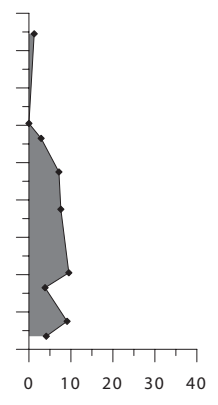

(\%)

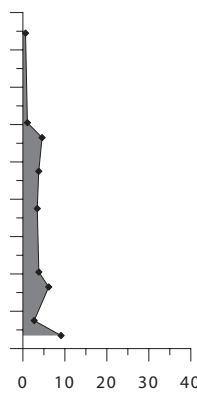

Q. seminula
$(\%)$

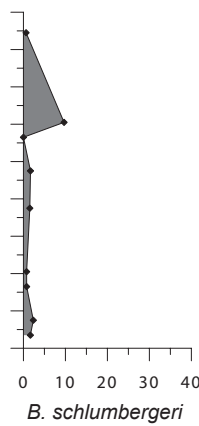

(\%)

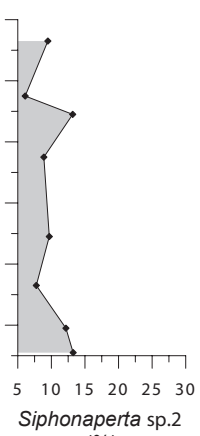

(\%)

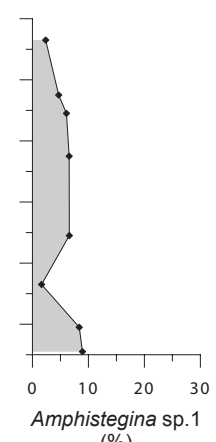

(\%)

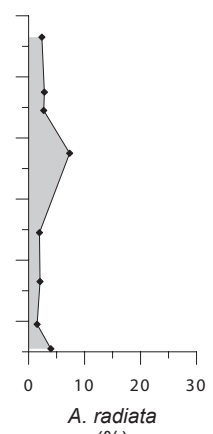

(\%)

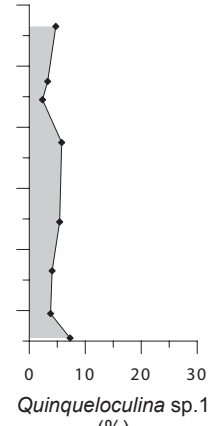

(\%)

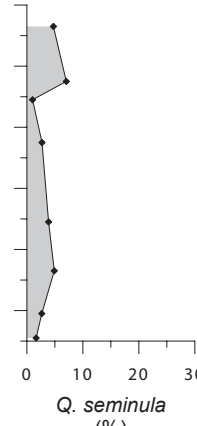

(\%)

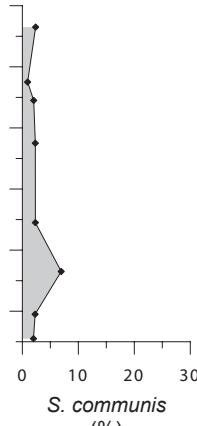

(\%)

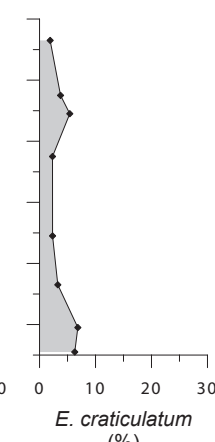

(\%)

Fig. 6. Distribution of the most abundant fossil benthic foraminifera in sediment cores 030310-C3 (A) and 050310-C4 (B). Only species with a relative abundance of $>5 \%$ on the fossil assemblages in the sediment cores are presented.

Table 4. Results of the detrended canonical correspondence analysis (DCCA). The short length of gradient for the first axis indicates a linear species-water-depth relationship in the surface samples.

\begin{tabular}{lrrrr}
\hline & 1 & 2 & 3 & 4 \\
\hline Eigenvalues & 0.236 & 0.123 & 0.07 & 0.017 \\
Lengths of gradient (SD) & 1.738 & 1.723 & 1.112 & 0.706 \\
\hline
\end{tabular}

averaging-partial least square (WA-PLS) method theoretically works better for gradient lengths of 2 and higher (Birks, 1998; Ter Braak et al., 1993), this method provided the best prediction potential from all methods applied. Moreover, this method can detect the influence of additional parameters such as substrate (Birks, 1998; Horton and Edwards, 2006).

The transfer function created by the WA-PLS method reveals a significant linear correlation $\left(R^{2}=0.97\right.$ and crossvalidated $\left.R_{\text {jack }}^{2}=0.92\right)$ between the observed and the estimated water depths in the surface data set for the selected second component (Table 5, Fig. 7). The residuals in the surface data set range between $-5.06 \mathrm{~m}$ and $2.71 \mathrm{~m}$ with a mean of $2.25 \mathrm{~m}$ (Fig. 8). The apparent root mean squared error (RMSE) and jack-knifed root mean squared error of prediction (RMSEP) for this component is $\pm 2.45 \mathrm{~m}$ and $\pm 4.09 \mathrm{~m}$, respectively, showing a relatively good predictive potential of the transfer function (Table 5).

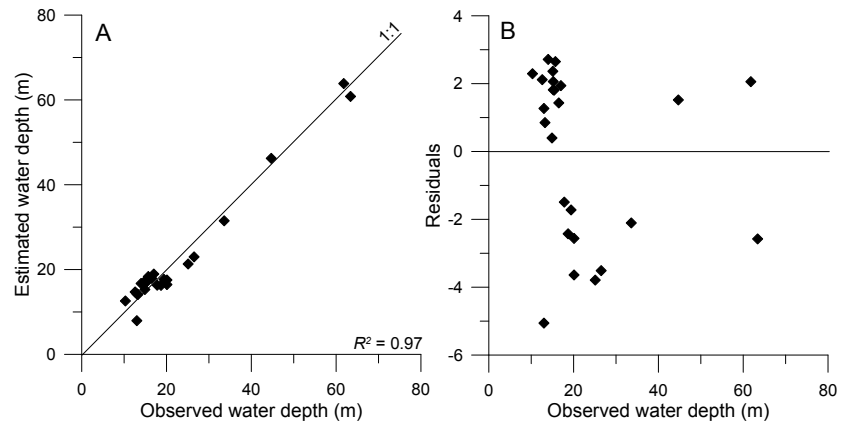

Fig. 7. Observed water depths versus estimated water depths by the WA-PLS transfer function in the surface samples (A) and their residuals (B).

To test the robustness of the transfer function, the application of the MAT method showed that, in core 030310-C3, one good analog and four fair analogs, but also four poor analogs with MinDC values above the 20th percentile, were found (Fig. 8). In core 050310-C4, two samples have good analogs with MinDC values below the 10th percentile and the remaining six core samples have fair analogs with values between the 10th and 20th percentile (Fig. 8). 

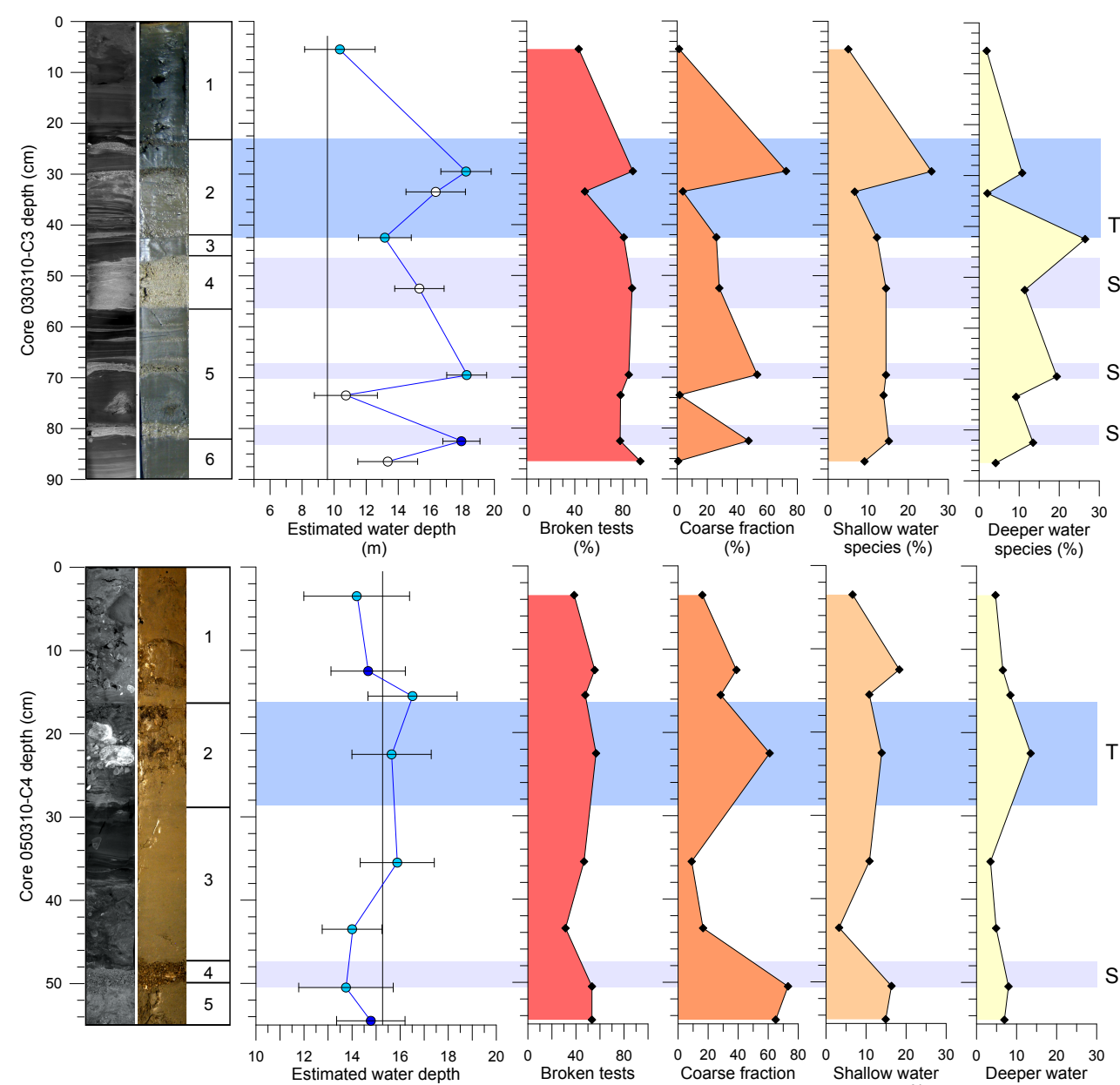

(\%)

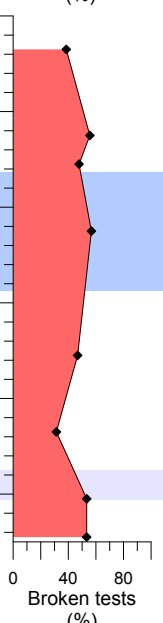

(\%)

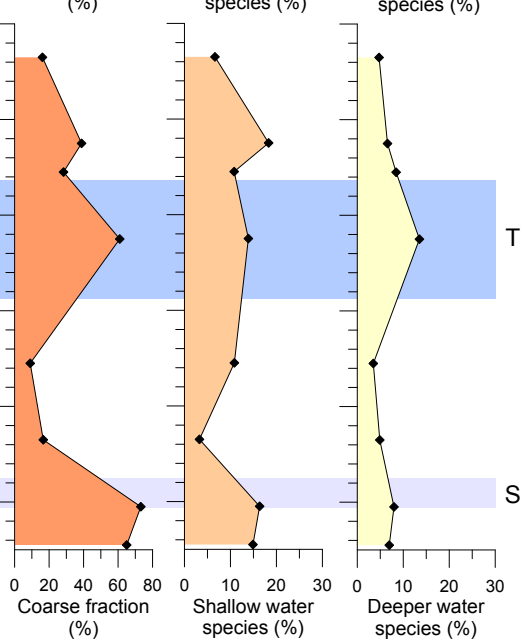

Fig. 8. Sediment core images with their lithological units (see also Fig. 2) and paleo-water depths in cores 030310-C3 and 050310-C4 estimated with the WA-PLS transfer function (open circles = bad analogs; light blue circles = fair analogs; blue circles = good analogs; calculated by modern analog technique). The vertical black lines mark the water depth where the sediment cores were taken. Further are shown the percentages of broken foraminiferal tests, proportion of the coarse fraction, and total relative abundances of species indicative for shallower water (B. schlumbergeri, P. stellata, A. lessonii, N. calcar, D. ambigua and Amphistegina sp.) and deeper water (A. radiata and O. ammonoides) in the study area (see also Figs. 3, 4 and 5). The shaded areas indicate storm layers (S) and the 2004 tsunami deposits (T).

Table 5. Results of the WA-PLS transfer function with the root mean squared error, the apparent coefficient of determination $\left(R^{2}\right)$, the cross-validated coefficient of determination $\left(R_{\text {jack }}^{2}\right)$, the root mean squared error of prediction (RMSEP) calculated by crossvalidation, and the reduction in RMSEP (\% change). The selected component for the paleo-water depth estimates in cores 030310-C3 and 050310-C4 is shown in bold.

\begin{tabular}{rrrrrr}
\hline Component & RMSE & $R^{2}$ & $R_{\text {jack }}^{2}$ & RMSEP & $\%$ change \\
\hline 1 & 4.50 & 0.90 & 0.85 & 5.46 & \\
$\mathbf{2}$ & $\mathbf{2 . 4 5}$ & $\mathbf{0 . 9 7}$ & $\mathbf{0 . 9 2}$ & $\mathbf{4 . 0 9}$ & $\mathbf{2 5 . 1 2}$ \\
3 & 1.67 & 0.99 & 0.92 & 3.98 & 2.69 \\
4 & 1.07 & 0.99 & 0.92 & 4.05 & -1.65 \\
5 & 0.79 & 1.00 & 0.92 & 3.94 & 2.63 \\
\hline
\end{tabular}

The paleo-water depths estimated with the transfer function range from $10.36( \pm 2.54) \mathrm{m}$ to $18.27( \pm 1.51) \mathrm{m}$ for core 030310-C3 and from $14.40( \pm 1.91) \mathrm{m}$ to $17.80( \pm 2.00) \mathrm{m}$ for core 050310-C4 (Fig. 8). The mean sample-specific error, calculated by bootstrapping, is $1.88 \mathrm{~m}$ for core 030310 $\mathrm{C} 3$ and $1.59 \mathrm{~m}$ for core $050310-\mathrm{C} 4$.

\section{Discussion}

\subsection{Ecology of benthic foraminifera in the study area}

Our results imply that both water depth and substrate act as relevant factors on the distribution of benthic foraminifers in the study area, explaining a large part of the observed faunal variability (Fig. 5). Similar relations have been reported from comparable environments of the lower photic zone on 
a mixed siliciclastic-carbonate inner shelf (e.g., Renema, 2006a). Many species and the majority of the identified faunas exhibit a distinct bathymetric zonation (Figs. 3 and 4). All faunas except for PC 4 (D. bertheloti fauna) contain symbiont-bearing larger benthic foraminifers as dominant or associated components. The relative bathymetric zonation and habitats of larger foraminifers off Khao Lak are comparable to other areas of the Indo-Pacific realm and, thus, are likely controlled by various physical and biological factors, most of which are related to the requirements of the species-specific symbiotic algae (Hallock, 1981; Hohenegger et al., 1999; Beavington-Penney and Racey, 2004; Renema, 2006b). The main factors include water temperature, light penetration, nutrient concentration, food availability and transport, energy at the benthic boundary layer and substrate type and grain size.

In the shallowest environments of the study area, between approximately 10 and $15 \mathrm{~m}$ water depth, three distinctive faunas are observed: the larger foraminifers $O$. ammonoides, $D$. ambigua and A. lessonii, which dominate PC5 in the shallow northern parts of the study area (Fig. 4), are typically associated with strong to medium light intensity, moderate to low water energy, and sands or rubble with sand on the reef flat (Hohenegger et al., 1999; Renema, 2006b). The distribution maximum of $A$. lessonii commonly occurs between 10 and $20 \mathrm{~m}$ water depth (Renema, 2006b), which is consistent with its occurrence in our study area (Fig. 3). In contrast, $O$. ammonoides has been reported from a wider depth interval, including distribution maxima between 10 and $30 \mathrm{~m}$ (Renema, 2006a), in other areas between 40 and $60 \mathrm{~m}$ (Hohenegger, 2004). Further to the south, this fauna is replaced by PC4, dominated by the non-symbiont-bearing $D$. bertheloti and Rosalina spp. (Figs. 3 and 4). The cosmopolitan species $D$. bertheloti inhabits various shelf and deep-sea environments and has a clear preference for fine-grained substrates (Milker et al., 2009), where it likely profits from specific biogeochemical conditions and the availability of sufficient food particles on and below the sediment surface. In the study area, this fauna is confined to depressions in the reef flat that operate as sediment traps for muddy sediments (Feldens et al., 2012). To the south, this fauna is replaced by the Pararotalia stellata fauna. Little is known on the ecology of this species, but it seems to be associated with sandy substrates and has been reported as typical inner-shelf taxon in the study area (Hawkes et al., 2007; Yawsangratt et al., 2011).

The environments at intermediate water depths are dominated by the Siphonaperta sp. 2 fauna between 15 and $25 \mathrm{~m}$, and the Amphistegina radiata fauna between 20 and $30 \mathrm{~m}$ water depth (Figs. 3 and 4). The larger foraminifer A. radiata is a characteristic taxon in both faunas and prefers firm substrates with maximum abundances between 20 and $40 \mathrm{~m}$ water depth, where it is adapted to variable light intensities and moderate to low water energy (Hohenegger et al., 1999; Hohenegger, 2004). This species commonly avoids the reef flat but is typical for rubble and macroalgal environments at the reef slope (Renema, 2006a). A similar adaption can be also inferred for the miliolid Siphonaperta sp. 2.

The deepest environments of the study area, below $30 \mathrm{~m}$ water depth, are characterized by $N$. praecinctus and $O$. complanata. The latter species typically replaces $O$. ammonoides at deeper sites and has been reported from sandy substrates between 30 and $90 \mathrm{~m}$ (in some areas down to $150 \mathrm{~m}$ ) water depth, where it is likely adapted to low light intensities and low water energy (Hohenegger, 2004; Renema, 2006b).

\subsection{Quantitative reconstruction of redeposition processes during the 2004 Indian Ocean tsunami}

Our results demonstrate significant redeposition of sediment particles in the offshore sediments during the 2004 Indian Ocean tsunami, including site-specific uprush and back-wash processes (Fig. 8). Our results are in general agreement with previous observations documenting the severe impacts of the tsunami event on coastal and shallow-water environments from the study area and adjacent regions (Bell et al., 2005; Tsuji et al., 2006; Hawkes et al., 2007). The tsunami-induced run-up at Pakarang Cape reached more than $15 \mathrm{~m}$ in height and resulted in the deposition of a few-centimeter-thick sandrich tsunamite layer (Szczucinski et al., 2005; Choowong et al., 2007; Hori et al., 2007, Jankaew et al., 2008, Brill et al., 2012). Goto et al. (2007) estimated that about $12500 \mathrm{~m}^{2}$ of Pakarang Cape were eroded by the 2004 Indian tsunami and a high amount of boulders were transported from offshore into the intertidal zone during the uprush. Hawkes et al. (2007) have shown that the shoreline of Thailand and Malaysia was influenced by up to three waves and a run-up of up to $2 \mathrm{~km}$ to the inland. Lay et al. (2005) reported inundation heights of up to $13 \mathrm{~m}$ for Sumatra, Thailand and Sri Lanka. On the inner shelf of the study area (9-15 $\mathrm{m}$ water depth), event layers of commonly $20-25 \mathrm{~cm}$ in thickness were identified as tsunami deposits (Sakuna et al., 2012). Based on the sedimentological observations and $210 \mathrm{~Pb}$ dating, assessing the decline in the excess of $210 \mathrm{~Pb}$ activities from the nearby area (Sakuna et al., 2012), the 2004 tsunami deposits are $18 \mathrm{~cm}$ thick in core 030310-C3 (lithological unit 2) and $13 \mathrm{~cm}$ thick in core 050310-C4 (lithological unit 2) (Figs. 2 and 8). Downcore, below the tsunami layers, we observed distinct sand layers in both cores, which were interpreted as storm layers. Core 030310-C3 contains three event layers, with one thicker layer in lithological unit 4 and two thinner layers in lithological unit 5. Core 050310-C4 contains one relatively thin event layer (lithological unit 4) (Figs. 2 and 8). The paleo-water depth estimates for core 030310-C3 indicate a sediment transport from deeper waters to the core location, similar for both the storm layers and the tsunamite (Fig. 8). The paleo-water depths estimated in the storm layers are $15.32 \pm 1.54 \mathrm{~m}$ for the storm layer in lithological unit 4 , and $17.94 \pm 1.42 \mathrm{~m}$ and $18.27 \pm 1.50 \mathrm{~m}$ for the lower and upper layer in lithological unit 5 , respectively. In the tsunami layer, 
we estimated paleo-water depths between $13.16 \pm 1.90 \mathrm{~m}$ and $18.23 \pm 1.68 \mathrm{~m}$. Based on the modern water depth of $9.5 \mathrm{~m}$ at this site our results demonstrate a net transport from deeper to shallower environments but also limit the reworking and resuspension of particles to a maximum water depth of approximately $20 \mathrm{~m}$. This result is supported by the low proportion of foraminifera (between two and four percent) in the core that in the present ocean occur in higher percentages at deeper water depths $(\sim 25$ to $\sim 60 \mathrm{~m})$ (Fig. 3 ). Based on the regional seafloor topography (Fig. 1), particles have been transported over approximately $5 \mathrm{~km}$ distance. The reconstructed maximum water depth of $20 \mathrm{~m}$ is lower than most previous reconstructions based on foraminifers that inferred resuspension depths of 45-300 m (Dominey-Howes et al., 1998; Nanayama and Shigeno, 2006; Uchida et al., 2010). Obviously, the energies and depth impacts of tsunami waves can vary significantly, based on the distance to the source area and the specific coastal morphology (Rabinovich et al., 2011). On the other hand, the majority of existing reconstructions are simply based on general assumptions and observations of benthic foraminiferal distribution ranges, lacking regional reference data sets and a robust statistical assessment. As a consequence, at least some of the reported maximum water depths could be overestimated since many species from middle and deeper shelf environments can also inhabit innershelf ecosystems, depending on the local presence of suitable (fine-grained) substrates and related microhabitats (Milker et al., 2009; Mojtahid et al., 2010; Goineau et al., 2011).

Within the tsunami layer of core $030310-\mathrm{C} 3$, changes to deeper paleo-water depths can be observed, likely representing changes in water energy and/ or an admixture of uprush and backwash events during successive tsunami waves (Fig. 8). The estimated deeper water depths in co-occurrence with a sand layer in the upper part of the tsunamite (around $30 \mathrm{~cm}$ ) may represent a subsequent uprush event, i.e., during a subsequent tsunami wave reaching the coastal area around Cape Pakarang. Our interpretation is supported by frequent occurrences of various species, such as $O$. complanata and A. radiata, in the surface samples from deeper water depths. At present, these species preferentially occur between 10 and $45 \mathrm{~m}$ water depth, and reach their optima at around $25 \mathrm{~m}$ and $35 \mathrm{~m}$ water depth, respectively (Figs. 3 and 8). However, the coeval occurrence of species that commonly prefer shallower water depths in the present ocean (B. schlumbergeri, N. calcar, P. stellata, D. ambigua, A. lessonii and Amphistegina sp.) do not support a clear provenance signal for this potential uprush event in the core (Figs. 3 and 8). Similarly, Hawkes et al. (2007) concluded from microfossil distributions in the Pulau Penang region of northern Malaysia that uprush events related to the 2004 tsunami are indicated by specimens derived from the inner shelf, while backwash layers contain more specimens recently found in mangrove sediments. Furthermore, Nanayama and Shigeno (2006) observed higher percentages of redeposited benthic foraminifera from water depths shallower than $45 \mathrm{~m}$ in uprush deposits of the 1993 Hokkaido tsunami.

Our paleo-water depth estimates in core 030310-C3, retrieved from $9.5 \mathrm{~m}$ water depth, reveal a provenance of particles in the tsunami layer from approximately 13 to $18 \mathrm{~m}$ water depth (Fig. 8). This result is in accordance with existing studies demonstrating that, within $8 \mathrm{~km}$ distance to the shoreline, the occurrence of the 2004 tsunami layer was restricted to a maximum water depth of 9 to $18 \mathrm{~m}$ (Feldens et al., 2012; Sakuna et al., 2012). These studies also attributed different lithologies and structures within the tsunamite to various phases of the tsunami event; i.e., marine sand layers were related to uprush and intercalated muddy intervals to backwash phases.

Our paleo-water depth reconstructions of core 050310$\mathrm{C} 4$ show that the particles within the tsunamite were derived from slightly deeper water depths of $16.94 \pm 1.56 \mathrm{~m}$ (Fig. 8). However, our reconstructions show a higher variability for this core, hampering a straightforward reconstruction of redeposition processes from the paleo-water depth estimates alone. The higher variability in the estimated paleowater depths in core 050310-C4 could be a consequence of the lower amount of larger foraminifera in this core. Larger foraminifera are particularly suitable for paleo-water depth estimations due to their stronger vertical zonation, which can be related to the light dependence of their symbionts and their dependence on hydrodynamic and trophic conditions, which can be linked to water depth (e.g., Hohenegger et al., 1999). In contrast, non-symbiont-bearing foraminifera occur over a wider depth range depending on the surrounding environmental conditions (Milker et al., 2009).

The sediments found in lithological unit 2, interpreted as the 2004 tsunami layer, contain terrestrial particles such as laterites, which indicates that this layer contains a mixture of particles derived from both uprush and backwash processes, inhibiting a clear distinction of the different phases of the tsunami event. The relatively high content of redeposited $A$. radiata and $O$. ammonoides in the middle part of the tsunami layer indicates sediment redeposition from water depths similar to that in core 030310-C3 (Fig. 8). The different percentages of redeposited specimens from deeper water in the two cores can be attributed to the different water depth of the core sites, representing different distances between source and deposition areas of the transported particles. This interpretation, however, is biased by the background redeposition processes that influence sedimentation of inner-shelf environments. The presence of bottom currents and wave action accounts for the overall significant percentages of relocated benthic foraminiferal tests in the recovered sediments of the study area (Fig. 8). Similar observations were also made by Yordanova and Hohenegger (2002) and Briguglio and Hohenegger (2011), indicating that downslope transport of larger benthic foraminifera due to normal wave activity can have significant influence on the accuracy of paleo-depth estimates because the real zonation of foraminifera can be 
masked by such redeposition processes. More specifically, Yordanova and Hohenegger (2007) observed that the buoyancy and entrainment potential of larger foraminiferal tests varies depending on their test shape and density.

Based on preliminary datings, a storm layer has been identified in the lower part of the core (unit 4). This layer is characterized by sandy sediment, whose high content of coarse particles contrasts with the adjacent sediments (Fig. 2). Our paleo-water depth reconstruction indicates a sediment transport from slightly shallower to deeper water $(14.04 \pm 1.78 \mathrm{~m})$. This result contrasts with observations from other areas, where sediment particles during comparable storm surges were preferentially transported from deeper to shallower water depths and where no backflow was observed (Nanayama et al., 2000).

Our data demonstrate that is not possible to distinguish tsunami deposits from background sedimentation based on the relative proportion of reworked particles. Instead, additional information on species composition is required for proper identification of high-energy events, particularly considering comprehensive data on the species distribution in the background sediment for comparison with the event layers.

\section{Conclusions}

For the first time, a transfer function for water depth reconstruction was developed on benthic foraminifers and applied to the reconstruction of redeposition processes and dynamics associated with the 2004 Indian Ocean tsunami. From our results we can extract the following conclusions:

- The distribution of recent benthic foraminifera on the inner shelf of the southeastern Andaman Sea off Khao Lak (Thailand) is typical for a tropical Indo-Pacific mixed siliciclastic-carbonate environment. The faunas exhibit not only a distinct bathymetric zonation but also a relation to the grain size of the substrate reflecting gradients in light intensity and water energy as well as specific microhabitats. A total of six assemblages have been distinguished, most of which including symbiont-bearing larger foraminifera as dominant and associated constituents. The shallowest sites, between 10 and $15 \mathrm{~m}$, are inhabited by three assemblages, comprising the Operculina ammonoides fauna, the Pararotalia stellata fauna, and the Discorbinella bertheloti fauna. The last is associated with muddy sediments trapped in depressions on the reef flat. The sandy sediments at intermediate water depth are inhabited by the Siphonaperta sp. 2 fauna (between 15 and $25 \mathrm{~m}$ ) and the Amphistegina radiata fauna (between 20 and $30 \mathrm{~m}$ ). The deepest sites (below $30 \mathrm{~m}$ ) are characterized by the Neoeponides praecinctus fauna adapted to low light intensities and low water energy.
- The distinct bathymetric zonation of most recent species allowed the development of a transfer function for quantitative water depth reconstructions with a high prediction potential. Our reconstructions for the 2004 Indian Ocean tsunami layer and pre-dating storm layers from two sites in the study area limit the maximum water depth of resuspension to approximately $20 \mathrm{~m}$. This value is considerably lower than most previous estimates for various tsunami events in the Indo-Pacific realm. On the other hand, the differentiation between storm and tsunami layers in the study area based on foraminifera remains problematic because both events reveal similar characteristics and redeposition processes.

\section{Appendix A}

\section{Species list}

Ammonia tepida (Cushman, 1926) - Melis and Violanti (2006), p. 98, pl. 1, Figs. 1-2

Amphistegina lessonii (d'Orbigny, 1843) - Jones (1994), p. 109, pl. 111, Figs. 4-7; Hohenegger et al. (1999), p. 144, Fig. 19

Amphistegina radiata (Fichtel and Moll, 1798) Hohenegger et al. (1999), p. 145, Fig. 20; Jones (1994), pl. 111, Fig. 3

Amphistegina sp. 1

Anomalinoides colligerus (Chapman and Parr, 1937) Jones (1994), p. 98, pl. 94, Figs. 2-3

Borelis schlumbergeri (Reichel, 1937) - Hottinger et al. (1993), p. 68, pl. 75, Figs. 1-17

Cibicidoides pseudoungerianus (Cushman, 1922) Cushman (1931), p. 123, pl. 22, Figs. 3-7; Milker and Schmiedl (2012), p. 106, Fig. 24.5-8

Dendritina ambigua (Fichtel and Moll, 1798) Hohenegger et al. (1999), p. 131, Fig. 10

Discorbinella bertheloti (d'Orbigny, 1839) - Hottinger et al. (1993), p. 114, pl. 150, Figs. 1-4

Elphidium craticulatum (Fichtel and Moll, 1798) - Hottinger et al. (1993), p. 147, pl. 208, Figs. 1-10; Hawkes et al. (2007); p. 178, pl. 2, Fig. 8

Neoeponides praecinctus (Karrer 1868) - Jones (1994), p. 99, pl. 95, Figs. 1-3

Neorotalia calcar (d'Orbigny, 1839) - Hottinger et al. (1993), p. 140, pl. 199, Figs. 1-10; Hohenegger et al. (1999), p. 146, Fig. 21

Operculina ammonoides (Gronovius, 1781) - Hohenegger et al. (1999), p. 155, Fig. 28

Operculina complanata (Defrance, 1822) - Jones (1994), p. 110, pl. 112, Figs. 3-9

Pararotalia stellata (de Férussac, 1827) - Jones (1994), p. 107, pl. 108, Fig. 3; Hawkes et al. (2007), p. 176, pl. 1, Figs. 1-3 
Parrellina hispidula (Cushman, 1936) - Melis and Violanti (2006), p. 98, pl. 1, Fig. 13; Berkeley et al. (2009), p. 84 , pl. 3, Fig. 7a, b

Quinqueloculina seminula (Linné, 1758) - Jones (1994), p. 21, pl. 5, Fig. 6

Quinqueloculina sp. 1

Saidovina subangularis (Brady, 1881) - Jones (1994), p. 59, pl. 53, Figs. 30, 31

Siphonaperta sp. 1

Siphonaperta sp. 2

Siphonaperta sp. 3

Spiroloculina communis Cushman and Todd (1944) Jones (1994), p. 25, pl. 9, Figs. 5-6

Triloculina oblonga (Montagu, 1803) - Berkeley et al. (2009), p.84, pl. 2, Fig. 5a, b, c

\section{Supplementary material related to this article is available online at http://www.nat-hazards-earth-syst-sci.net/13/3113/2013/ nhess-13-3113-2013-supplement.pdf.}

Acknowledgements. For technical support during preparation of samples we thank Eva Vinx and Jutta Richarz at the Center of Earth System Research and Sustainability, Hamburg University. We further want to thank Johann Hohenegger and an anonymous reviewer for their constructive comments helping to improve the manuscript. The project from which the samples originate was funded by Deutsche Forschungsgemeinschaft (DFG) grant SCHW 572/11 and the National Research Council of Thailand (NRCT).

Edited by: H. Sterr

Reviewed by: J. Hohenegger and one anonymous referee

\section{References}

Backhaus, K., Erichson, B., Plinke, W., and Weiber, R.: Multivariate Analysemethoden, 11th Edn., Springer, Berlin, Heidelberg, New York, 2006.

Beavington-Penney, S. J. and Racey, A.: Ecology of extant nummulitids and other larger benthic foraminifera: applications in palaeoenvironmental analysis, Earth-Sci. Rev., 67, 219-265, 2004.

Bell, R., Cowan, H., Dalziell, E., Evans, N., O'Leary, M., Rush, B., and Yule, L.: Survey of impacts on the Andaman coast, southern Thailand following the great Sumatra-Andaman earthquake and tsunami of December 26, 2004, Bull. New Zealand Soc. Earth. Eng., 38, 124-148, 2005.

Berkeley, A., Perry, C. T., Smithers, S. G., Horton, B. P., and Cundy, A. B.: Foraminiferal biofacies across mangrove-mudflat environments at Cocoa Creek, north Queensland, Australia, Mar. Geol., 263, 64-86, 2009.

Birks, H. J. B.: Quantitative palaeoenvironmental reconstructions, in: Statistical Modelling of Quaternary Science Data, edited by: Maddy, D. and Brew, J. S., Cambridge, 161-254, 1995.
Birks, H. J. B.: Numerical tools in palaeolimnology - Progress, potentialities, and problems, J. Paleolimnol., 20, 307-332, 1998.

Birks, H. J. B., Line, J. M., Juggins, S., Stevenson, A. C., and Ter Braak, C. J. F.: Diatoms and $\mathrm{pH}$ reconstruction, Phil. Trans. R. Soc. Lond., B 327, 263-278, 1990.

Brill, D., Klasen, N., Jankaew, K., Brückner, H., Kelletat, D., Scheffers, A., and Scheffers, S.: Local inundation distances and regional tsunami recurrence in the Indian Ocean inferred from luminescence dating of sandy deposits in Thailand, Nat. Hazards Earth Syst. Sci., 12, 2177-2192, doi:10.5194/nhess-12-21772012, 2012.

Briguglio, A. and Hohenegger, J.: How to react to shallow water hydrodynamics: The larger benthic foraminifera solution, Mar. Micropalaeontol., 81, 63-76, doi10.1016/j.marmicro.2011.07.004, 2011.

Choowong, M., Murakoshi, N., Hisada, K., Charusiri, P., Daorerk, V., Charoentitirat, T., Chutakositkanon, V., Jankaew, K., and Kanjanapayont, P.: Erosion and deposition by the 2004 Indian Ocean tsunami in Phuket and Phang-nga provinces, Thailand. J. Coastal Res., 23, 1270-1276, 2007.

Cushman, J. A.: The foraminifera of the Atlantic Ocean, Part 8: Rotaliidae, Amphisteginidae, Calcarinidae, Cymbalporettidae, Globorotallidae, Anomalinidae, Planorbulinidae, Pupertiidae and Homotremidae, Smithonian Institution, United States National Museum, Bulletin 104, Washington, 1931.

Dahanayake, K. and Kulasena, N.: Recognition of diagnostic criteria for recent- and paleo-tsunami sediments from Sri Lanka, Mar. Geol., 254, 180-186, doi:10.1016/j.margeo.2008.06.005, 2008.

Dominey-Howes, D., Dawson, A., and Smith, D.: Late Holocene coastal tectonics at Falasarna, western Crete: a sedimentary study, in: Coastal Tectonics, edited by: Stewart, I. and Vita-Finzi, C., Special Publications, Geological Society, London, 343-352, 1998.

Fagherazzi, S. and Du, X.,: Tsunamigenic incisions produced by the December 2004 earhquake along the coasts of Thailand, Indonesia and Sri Lanka, Geomorphology, 99, 120-129, doi:10.1016/j.geomorph.2007.10.015, 2007.

Feldens, P., Schwarzer, K., Szczuciński, W., Stattegger, K., Sakuna, D., and Somgpongchaiykul, P.: Impact of 2004 tsunami on seafloor morphology and offshore sediments, Pakarang Cape, Thailand, Polish J. Environ. Stud, 18, 63-68, 2009.

Feldens, P., Schwarzer, K., Sakuna, D., Szczucinski, W., and Sompongchaiyakul, P.: Sediment distribution on the inner continental shelf off Khao Lak (Thailand) after the 2004 Indian Ocean tsunami, Earth Planet. Space, 64, 875-887, 2012.

Goineau, A., Fontanier, C., Jorissen, F. J., Lansard, B., Buscail, R., Mouret, A., Kerhervé, P., Zaragosi, S., Ernoult, E., Artéro, C., Anschutz, P., Metzger, E., and Rabouille, C.: Live (stained) benthic foraminifera from the Rhône prodelta (Gulf of Lion, NW Mediterranean): Environmental controls on a river-dominated shelf, J. Sea Res., 65, 58-75, 2011.

Goto, K., Chavanich, S. A., Imamura, F., Kunthasap, P., Matsui, T., Minoura, K., Sugawara, D., and Yanagisawa, H.: Distribution, origin and transport process of boulders deposited by the 2004 Indian Ocean tsunami at Pakarang Cape, Thailand, Sediment. Geol., 202, 821-837, 2007.

Hallock, P.: Algal symbiosis: A mathematical analysis, Mar. Biol., 62, 249-255, 1981. 
Hawkes, A. D., Bird, M., Cowie, S., Grundy-Warr, C., Horton, B. P., Tan Shau Hwai, A., Law, L., Macgregor, C., Nott, J., Eong Ong, J., Rigg, J., Robinson, R., Tan-Mullins, M., Tiong Sa, T., Yasin, Z., and Wan Aik, L.: Sediments deposited by the 2004 Indian Ocean Tsunami along the Malaysia-Thailand Peninsula, Mar. Geol., 242, 169-190, 2007.

Hawkes, A. D., Horton, B. P., Nelson, A. R., and Hill, D. F.: The application of intertidal foraminifera to reconstruct coastal subsidence during the giant Cascadia earthquake of AD 1700 in Oregon, USA, Quaternary Int., 122, 116-140, 2010.

Hohenegger, J.: Depth coenoclines and environmental considerations of western pacific larger foraminifera, J. Foramin. Res., 34, 9-33, 2004.

Hohenegger, J.: Estimation of environmental paleogradient values based on presence/absence data: a case study using benthic foraminifera for paleodepth estimation, Palaeogeogr. Palaeocl., 217, 115-130, 2005

Hohenegger, J., Yordanova, E., Nakano, Y., and Tatzreiter, F.: Habitats of larger foraminifera on the upper reef slope of Sesoko Island, Okinawa, Japan, Mar. Micropalaeontol., 36, 109-168, 1999.

Hori, K., Kuzumoto, R., Hirouchi, D., Umitsu, M., Janjirawuttikul, N., and Patanakanog, B.: Horizontal and vertical variation of 2004 Indian tsunami deposits: An example of two transects along the western coast of Thailand, Mar. Geol., 239, 163-172, doi:10.1016/j.margeo.2007.01.005, 2007.

Horton, B. P. and Edwards, R. J.: Quantifying Holocene sea-level change using intertidal foraminifera: Lessons from the British Isles, Cushman Foundation for Foraminiferal Research, Special publication No. 40, 1-97, 2006.

Horton, B. P., Edwards, R. J., and Lloyd, J. M.: A foraminiferalbased transfer function: Implications for sea-level studies, J. Foramin. Res., 29, 117-129, 1999.

Hottinger, L., Halicz, E., and Reiss, Z.: Recent foraminiferida from the Gulf of Aqaba, Red Sea, Academia Scientarum et Artium Slovenica, Classis IV: Historia Naturalis, Lubljana, 179 pp., 1993.

Jankaew, K., Atwater, B. F., Sawai, Y., Choowong, M. Charoentitirat, T., Martin M. E., and Prendergast, A.: Mediveal forewarning of the 2004 Indian Ocean Tsunami in Thailand, Nature, 455, 1228-1231, 2008.

Jones, R. W.: The Challenger Foraminifera, 1st Edn., Oxford University Press Inc., New York, 149 pp., 1994.

Juggins, S.: Software for ecological and palaeoecological data analysis and visualisation, Tutorial Version 1.3, 1-24, 2003.

Kemp, A. C., Horton, B. P., Corbett, R., Culver, S. J., Edwards, R. J., and van de Plassche, O.: The relative utility of foraminifera and diatoms for reconstructing late Holocene sea-level change in North Carolina, USA, Quaternary Res., 71, 9-21, 2009.

Kortegaas, S. and Dawson, A. G.: Distinguishing tsunami and storm deposits: An example from Martinhal, SW Portugal, Sediment. Geol., 200, 208-221, doi:10.1016/j.sedgeo.2007.01.004, 2007.

Kumar, V. S., Babu, V. R., Babu, M. T., Dhinakaran, G., and Rajamanickam, G. V.: Assessment of storm surge disaster potential for the Andaman Islands, J. Coastal Res., 24, 171-177, doi:10.2112/05-0506.1, 2008.

Lay, T., Kanamori, H., Ammon, C. J., Nettles, M., Ward, S. N., Aster, R. C., Beck, S. L., Bilek, S. L., Brudzinski, M. R., Butler, R., DeShon, H. R., Ekström, G., Satake, K., and Sipkin, S.:
The great Sumatra-Andaman Earthquake of 26 December 2004 Science, 308, 1127-1132, 2005.

Leps, J. and Smilauer, P.: Multivariate analysis of ecological data using CANOCO, Cambridge University Press, Cambridge, 269 pp., 2003.

Levitus, S., and Boyer, T. P.: World Ocean Atlas 1994, Volume 4. Temperature, National Environmental Satellite, Data, and Information Service, Washington, DC (United States), 1994.

Malmgren, B. A. and Haq, B. U.: Assessmant of quantitative techniques in paleobiogeography, Mar. Micropaleontol., 7, 213-230, 1982.

Mamo, B., Strotz, L., and Dominey-Howes, D.: Tsunami sediments and their foraminiferal assemblages, Earth-Sci. Rev., 96, 263 278, 2009.

Mard Karlsson, J., Skelton, A., Sandén, M, Ioualalen, M., Kaewbanjak, N., Pophet, N., Asavanant, J., and von Matern, A.: Reconstructions of the coastal impact of the 2004 Indian Ocean tsunami in the Khao Lak area, Thailand, J. Geophys. Res., 114, C10023, doi:10.1029/2009JC005516, 2009.

Melis, R. and Violanti, D.: Foraminiferal biodiversity and Holocene evolution of the Phetchaburi coastal area (Thailand Gulf), Mar. Micropalaeontol., 61, 94-115, 2006.

Milker, Y. and Schmiedl, G.: A taxonomic guide to modern benthic shelf foraminifera of the western Mediterranean Sea., Palaeontol. Electron., 15, 1-134, 2012.

Milker, Y., Schmiedl, G., Betzler, C., Römer, M., JaramilloVogel, D., and Siccha, M.: Distribution of Recent benthic foraminifera in neritic carbonate environments of the Western Mediterranean Sea, Mar. Micropalaeontol., 73, 207-225, doi:10.1016/j.marmicro.2009.10.003, 2009.

Milker, Y., Schmiedl, G., and Betzler, C.: Paleobathymetric history of the Western Mediterranean Sea shelf during the latest glacial period and the Holocene: Quantitative reconstructions based on foraminiferal transfer functions, Palaeogeogr. Palaeocl., 307, 324-338, doi:10.1016/j.palaeo.2011.05.031, 2011.

Mojtahid, M., Jorissen, F., Lansard, B., and Fontanier, C.: Microhabitat selection of benthic foraminifera in sediments off Rhone river mouth (NW Mediterranean), J. Foram. Res., 40, 231-246, doi:10.2113/gsjfr.40.3.231, 2010.

Morton, R. A., Gelfenbaum, G., and Jaffe, B. E.: Physical criteria for distinguishing sandy tsunami and storm deposits using modern examples, Sediment. Geol., 200, 184-207, doi:10.1016/j.sedgeo.2007.01.003, 2007.

Murray, J. W.: Ecology and Applications of Benthic Foraminifera, Cambridge University Press, Cambridge, 2006.

Nanayama, F. and Shigeno, K.: Inflow and outflow facies from the 1993 tsunami in southwest Hokkaido, Sediment. Geol., 187, 139-158, 2006.

Nanayama, F., Shigeno, K., Satake, K., Shimokawa, K., Koitabashi, S., Miyasaka, S., and Ishii, M.: Sedimentary differences between the 1993 Hokkaido-nansei-oki tsunami and the 1959 Miyakojima typhoon at Taisei, southwestern Hokkaido, northern Japan, Sediment. Geol., 135, 255-264, 2000.

Nelson, A. R., Sawai, Y., Jennings, A. E., Bradley, L.-A., Gerson, L., Sherrod, B. L., Sabean, J., and Horton, B. P.: Greatearthquake paleogeodesy and tsunamies of the past 2000 years at Alsea Bay, central Oregon coast, USA, Quaternary Sci. Rev., 27, 747-768, 2008. 
Overpeck, J. T., Webb III., T., and Prentice, I. C.: Quantitative interpretation of fossil pollen spectra: Dissimilarity coefficients and the method of Modern Analogs, Quaternary Res., 23, 87-108, 1985.

Parker, J. H. and Gischler, E.: Modern foraminiferal distribution and diversity in two atolls from the Maldives, Indian Ocean, Mar. Micropaleontol., 78, 30-49, 2011.

Phantuwongraj, S., and Choowong, M.: Tsunamis versus storm deposits from Thailand, Nat. Hazards, 63, 31-50, 2012.

Rabinovich, A. B., Candella, R. N., and Thomson, R. E.: Energy Decay of the 2004 Sumatra Tsunami in the World Ocean, Pure Appl. Geophys, 168, 1919-1950, 2011.

Renema, W.: Large benthic foraminifera from the deep photic zone of a mixed siliciclastoc-carbonate shelf off East Kalimantan, Indonesia, Mar. Micropaleontol., 58, 73-82, 2006a.

Renema, W.: Habitat variables determining the occurrence of large benthic foraminifera in the Berau area (East Kalimantan, Indonesia), Coral Reefs, 25, 351-359, 2006b.

Rossi, V. and Horton, B. P.: The application of subtidal foraminifera-based transfer function to reconstruct Holocene paleobathymetry of the Po Delta, northern Adriatic Sea, J. Foramin. Res., 39, 180-190, 2009.

Saidova, K. M.: Benthic foraminifera communities of the Andaman Sea (Indian Ocean), Oceanology, 48, 517-523, 2008.

Sakuna, D., Szczucinski, W., Feldens, P., Schwarzer, K., and Khokiattiwong, S.: Sedimentary deposits left by the 2004 Indian Ocean tsunami on the inner continental shelf offshore of Khao Lak, Andaman Sea (Thailand), Earth Planet. Space, 64, 931-943, 2012.

Satyanarayana, A., Nallapa Reddy, A., Jaiprakash, B. C., and Chidambaram, L.: A note on foraminifera, grain size and clay mineralogy of tsunami sediments from Karaikal-NagoreNagapattinam beaches, Southeast coast of India, J. Geol. Soc. India, 69, 70-74, 2007.

Scheffers, A., Brill, D., Kelletat, D., Brückner, H., Scheffers, S., and Fox, K.: Holocene sea levels along the Andaman Sea coast of Thailand, Holocene, 22, 1169-1180, 2012.

Stein, S. and Okal, E. A.: Speed and size of the Sumatra earthquake, Nature, 434, 581-582, 2005.

Sugawara, D., Minoura, N., Tsukawaki, S., Goto, K., and Imamura, F.: Foraminiferal evidence of submarine sediment transport and deposition by backwash during the 2004 Indian Ocean tsunami, Isl. Arc, 18, 513-525, 2009.

Szarek, R., Kuhnt, T., Kawamura, H., and Kitazato, H.: Distribution of recent benthic foraminifera on the Sunda Shelf (South China Sea), Mar. Micropaleontol., 61, 171-195, 2006.
Ter Braak, C. J. F. and Juggins, S.: Weighted averaging partial least squares regression (WA-PLS): an improved method for reconstructing environmental variables from species assemblages, Hydrobiologia, 269/270, 485-502, 1993.

Ter Braak, C. J. F. and Smilauer, P.: CANOCO Reference manual and CanoDraw for Windows User's guide (version 4.5), Microcomputer power Ithaka, NY, USA, 500 pp., 2002.

Ter Braak, C. J. F., Juggins, S., Birks, H. J. B., and Van der Voet, H.: Weighted Averaging Least Squares regression (WA-PLS): definition and comparison with other methods for species-environment calibration, in: Multivariate Environmental Statistics, edited by: Patil, G. P. and Rao, C. R., Elsevier Science Publishers B.V. (North Holland), Amsterdam, 525-560, 1993.

Thampanya, U., Vermaat, J. E., Sinsakul, S., and Panapitukkul, N.: Coastal erosion and mangrove progradation of Southern Thailand, Estuar. Coast. Shelf S., 68, 75-85, 2006.

Tsuji, Y., Namegaya, Y., Matsumoto, H., Iwasaki, S.-I., Kanbua, W., Sriwichai, M., and Meesuk, V.: The 2004 Indian tsunami in Thailand: Surveyed runup heights and tide gauge records, Earth Planet. Space, 58, 223-232, 2006.

Uchida, J.-I., Fujuwara, O., Hasegawa, S., and Kamataki, T.: Sources and depositional processes of tsunami deposits: Analysis using foraminiferal tests and hydrodynamic verification, Isl. Arc, 19, 427-442, 2010.

Van der Zwaan, G. J., Jorissen, F. J., and de Stigter, H. C.: The depth dependency of planktonic/benthic foraminiferal ratios: Constraints and applications, Mar. Geol., 95, 1-16, 1990.

Varkey, M. J., Murty, V. S. N., and Suryanarayana, A.: Physical oceanography of the Bay of Bengal and Andaman Sea, Oceanogr. Mar. Biol. Ann. Rev, 34, 1-70, 1996.

Yawsangratt, S., Szczucinski, W., Chaimanee, N., Chatprasert, S., Majewski, W., and Lorenc, S.: Evidence of probable paleotsunami deposits on Kho Khao Island, Phang Nga Province, Thailand, Nat. Hazards, 23, 1270-1276, doi:10.2112/05-0561.1, 2011.

Yordanova, E. K. and Hohenegger, J.: Taphonomy of larger foraminifera: Relationships between living individuals and empty tests on flat reef slopes (Sesoko Island, Japan), Facies, 46, 169-203, doi:10.1007/BF02668080, 2002.

Yordanova, E. K. and Hohenegger, J.: Studies on settling, traction and entrainment of larger benthic foraminiferal tests: implications for accumulation in shallow marine sediments, Sedimentology, 54, 1273-1306, doi:10.1111/j.1365-3091.2007.00881.x, 2007. 